Article

\title{
Leaf-Scale Study of Biogenic Volatile Organic Compound Emissions from Willow (Salix spp.) Short Rotation Coppices Covering Two Growing Seasons
}

\author{
Tomas Karlsson ${ }^{1, * \mathbb{D}}$, Leif Klemedtsson ${ }^{2}$, Riikka Rinnan ${ }^{3}$ and Thomas Holst ${ }^{1}$ (D) \\ 1 Department of Physical Geography and Ecosystem Science, Lund University, Sölvegatan 12, \\ 22362 Lund, Sweden; thomas.holst@nateko.lu.se \\ 2 Department of Earth Sciences, University of Gothenburg, Guldhedsgatan 5a, 40530 Gothenburg, Sweden; \\ leif.klemedtsson@gvc.gu.se \\ 3 Terrestrial Ecology Section, Department of Biology, University of Copenhagen, Universitetsparken 15, \\ DK-2100 Copenhagen, Denmark; riikkar@bio.ku.dk \\ * Correspondence: tomas.karlsson@nateko.lu.se
}

Citation: Karlsson, T.; Klemedtsson, L.; Rinnan, R.; Holst, T. Leaf-Scale Study of Biogenic Volatile Organic Compound Emissions from Willow (Salix spp.) Short Rotation Coppices Covering Two Growing Seasons. Atmosphere 2021, 12, 1427. https://doi.org/10.3390/ atmos12111427

Academic Editor: Anthony R. Lupo

Received: 14 September 2021

Accepted: 16 October 2021

Published: 29 October 2021

Publisher's Note: MDPI stays neutral with regard to jurisdictional claims in published maps and institutional affiliations.

Copyright: (c) 2021 by the authors. Licensee MDPI, Basel, Switzerland. This article is an open access article distributed under the terms and conditions of the Creative Commons Attribution (CC BY) license (https:// creativecommons.org/licenses/by/ $4.0 /)$.
Abstract: In Europe, willow (Salix spp.) trees have been used commercially since the 1980s at a large scale to produce renewable energy. While reducing fossil fuel needs, growing short rotation coppices (SRCs), such as poplar or willow, may have a high impact on local air quality as these species are known to produce high amounts of isoprene, which can lead to the production of tropospheric ozone $\left(\mathrm{O}_{3}\right)$. Here, we present a long-term leaf-scale study of biogenic volatile organic compound (BVOC) emissions from a Swedish managed willow site with the aim of providing information on the seasonal variability in BVOC emissions during two growing seasons, 2015-2016. Total BVOC emissions during these two seasons were dominated by isoprene ( $>96 \%$ by mass) and the monoterpene (MT) ocimene. The average standardized (STD, temperature of $30^{\circ} \mathrm{C}$ and photosynthetically active radiation of $\left.1000 \mu \mathrm{mol} \mathrm{m}^{-2} \mathrm{~s}^{-1}\right)$ emission rate for isoprene was $45.2( \pm 42.9$, standard deviation (SD)) $\mu \mathrm{g} \mathrm{g}_{\mathrm{dw}}{ }^{-1} \mathrm{~h}^{-1}$. Isoprene varied through the season, mainly depending on the prevailing temperature and light, where the measured emissions peaked in July 2015 and August 2016. The average STD emission for MTs was $0.301( \pm 0.201) \mu \mathrm{g} \mathrm{g}_{\mathrm{dw}}{ }^{-1} \mathrm{~h}^{-1}$ and the MT emissions decreased from spring to autumn. The average STD emission for sesquiterpenes (SQTs) was $0.103( \pm 0.249) \mu \mathrm{g} \mathrm{gdw}^{-1} \mathrm{~h}^{-1}$, where caryophyllene was the most abundant SQT. The measured emissions of SQTs peaked in August both in 2015 and 2016. Non-terpenoid compounds were grouped as other VOCs $\left(0.751 \pm 0.159 \mu \mathrm{g} \mathrm{g}_{\mathrm{dw}}{ }^{-1} \mathrm{~h}^{-1}\right)$, containing alkanes, aldehydes, ketones, and other compounds. Emissions from all the BVOC groups decreased towards the end of the growing season. The more sun-adapted leaves in the upper part of the plantation canopy emitted higher rates of isoprene, MTs, and SQTs compared with more shade-adapted leaves in the lower canopy. On the other hand, emissions of other VOCs were lower from the upper part of the canopy compared with the lower part. Light response curves showed that ocimene and $\alpha$-farnesene increased with light but only for the sun-adapted leaves, since the shade-adapted leaves did not emit ocimene and $\alpha$-farnesene. An infestation with Melampsora spp. likely induced high emissions of, e.g., hexanal and nonanal in August 2015. The results from this study imply that upscaling BVOC emissions with model approaches should account for seasonality and also include the canopy position of leaves as a parameter to allow for better estimates for the regional and global budgets of ecosystem emissions.

Keywords: Salix plantation; willow; leaf rust; terpenoids; non-terpenoids; BVOCs; leaf-scale; GC-MS

\section{Introduction}

The increase in greenhouse gases (GHGs) and the global temperature during the last few decades have resulted in mitigation strategies and climate targets, where the main goal is to keep the average global temperature increase within $1.5-2{ }^{\circ} \mathrm{C}[1,2]$ compared 
with pre-industrial levels. Together with these climate targets, as declared by the European Union, Sweden also has the goal to have no net emission of GHGs into the atmosphere by 2045 [3]. One option to decrease the use of and dependency on fossil fuel is to use fast-growing biofuel crops, also known as short rotation coppices (SRCs) [4].

Perennial crops are well suited for this purpose and, in particular, willow trees (Salix spp.) have been used to produce energy in district heating plants since the 1980s [5]. By using life cycle assessment (LCA), willow as biomass-based energy can reduce the GHG emissions considerably compared with fossil fuel [6]. One of the advantages with willow is the possibility of hybridization and propagation, which makes it easy to develop new varieties for better biomass yield [7]. After initial establishment, the trees grow for between 3 and 5 years before their aboveground biomass is harvested, and plants continue to regrow from their root system for the next harvest cycle. Compared with annual crops, Salix trees do not need as much management and fertilization [8]. Current land use of SRC plantations in Sweden is just below 10,000 ha but it has been estimated that this area could expand to 200,000-300,000 ha [9]. Besides the climate change mitigation effects, Salix has some other environmental benefits. The plant takes up heavy metals, such as cadmium, from soil [10,11], and can thus be used to clean the soil after application of sludge and wastewater $[9,12]$.

However, Salix trees emit high amounts of biogenic volatile organic compounds (BVOCs) [13]. BVOCs are used by plants for signaling, to attract pollinators, and to protect the plants against biotic stress (e.g., herbivory and pathogens) and abiotic stress (e.g., extreme temperatures or pollutants such as ozone $\left(\mathrm{O}_{3}\right)$ [14-19]. However, BVOCs are also important for atmospheric chemistry as they reduce the amount of hydroxyl radicals and thus increase the lifetime of $\mathrm{CH}_{4}[20,21]$. The production of $\mathrm{O}_{3}$ is influenced by the prevailing ratio between VOCs and $\mathrm{NO}_{X}$ [22]. BVOCs could therefore efficiently contribute to the production of tropospheric $\mathrm{O}_{3}$ in non- $\mathrm{NO}_{\mathbf{X}}$-limited situations [23-25]. Tropospheric $\mathrm{O}_{3}$ is hazardous as it damages the leaf tissue when entering the stomata, leading to a lower photosynthetic capacity $[26,27]$, but the sink strength of $\mathrm{O}_{3}$ depends also on the stomatal conductance and thus on the ambient environmental conditions $[28,29]$. Since $\mathrm{O}_{3}$ is a GHG, and also could reduce the ability of plants to absorb $\mathrm{CO}_{2}$, an increase in $\mathrm{O}_{3}$ might lead to an enhancement in radiative forcing and global warming [30,31]. In addition, BVOCs act as precursors for secondary organic aerosols (SOAs) and enhance cloud condensation nuclei (CCN) production [32-39]. Depending on the properties of the aerosols and the environmental conditions, they can either decrease or enhance global warming [38], but the overall impact of CCN and SOAs is believed to cool the earth [40].

To our knowledge, few studies have investigated the whole emission spectrum of BVOCs from Salix [41,42] since the focus has mostly been on isoprene [43,44]. Some studies (e.g., [45]) have investigated emissions from Salix at different heights within the canopy. The BVOC emissions from the leaves within the canopy are expected to vary due to the different microclimatic conditions (e.g., temperature and radiation) [45,46], but the difference might be less pronounced for the standardized (STD) emissions.

This study aims to characterize BVOC emissions from Salix trees growing in their last year before harvest during the major part of the growing season. Our objectives were to determine seasonal trends in emission rates and spectra, and to assess for differences between leaves growing at different heights within the canopy.

\section{Methods}

\subsection{Site Description}

Measurements were done on two plantations in Skrehalla ( $\mathrm{P} 1,58^{\circ} 16^{\prime} 55^{\prime \prime} \mathrm{N} 12^{\circ} 46^{\prime} 20^{\prime \prime} \mathrm{E}$ and $\mathrm{P} 2,58^{\circ} 17^{\prime} 09^{\prime \prime} \mathrm{N} 12^{\circ} 45^{\prime} 31^{\prime \prime} \mathrm{E}$ ), which were located in the southwestern part of Sweden and about $80 \mathrm{~km}$ northeast of Gothenburg (Figure S1). The area is flat and the site was mainly surrounded by arable fields. The long-term mean annual temperature was $6.1{ }^{\circ} \mathrm{C}$ (1961-1990 in Gendalen, located $16 \mathrm{~km}$ from the site) and the annual precipitation was $683 \mathrm{~mm}$ (1961-1990 in Grästorp, $7 \mathrm{~km}$ from the site) [47]. The soil in the area contained 
clay or a silty clay loam with $34-36 \%$ clay content, $45-46 \%$ silt content, and no organic content (Table 1). Willow trees growing on P1 originated from the species S. viminalis. This plantation was established in 1994 and the last time the trees were harvested was in the beginning of 2013, which means measurements were done during their third growing season in 2015. In total, P1 covered approximately 6 ha. The variety growing on P2 is called Tora and P2 was established in 2003 on an area of approximately 5 ha. The trees on P2 were harvested in spring 2013, which means they were in their fourth growing season in 2016. At both sites, all trees were planted in double rows, separated by $0.75 \mathrm{~m}$ and $1.25 \mathrm{~m}$ between each double row. The distance between the trees in the row was $0.4 \mathrm{~m}$.

Table 1. Information about the two plantations (P1 and P2) in the study. Size (ha), previous land use, year of establishment, canopy height $(\mathrm{m})$, leaf area index (LAI, $\left.\mathrm{m}^{2} \mathrm{~m}^{-2}\right)$, soil type and content, treatments, varieties, and yield $\left(\mathrm{m}^{3} \mathrm{ha}^{-1}\right)$.

\begin{tabular}{ccc}
\hline & P1 & P2 \\
\hline Size & 6 ha & 5 ha \\
Formerly used for & cereals & Salix \\
Established & 1994 & 2003 \\
Canopy height $^{1}$ & $4.5 \mathrm{~m}$ & $7 \mathrm{~m}$ \\
LAI $^{2}$ & 5.5 & 4.9 \\
Soil type $^{3}$ & silty clay loam & clay loam \\
Clay content $^{3}$ & $36 \%$ & $34 \%$ \\
Silt content $^{3}$ & $46 \%$ & $45 \%$ \\
Organic content $^{3}$ & $0 \%$ & $0 \%$ \\
Treatments $^{4}$ & Fertilized (ca $\left.2 \times 100 \mathrm{~kg} \mathrm{~N} \mathrm{ha}^{-1}\right)$ & Fertilized (ca $1 \times 100 \mathrm{~kg} \mathrm{~N} \mathrm{ha}^{-1}$ ) \\
Varieties & unknown S. viminalis & Tora \\
Last harvest $^{\text {Yield }}{ }^{5}$ & 2013 & 2013 \\
\hline
\end{tabular}

${ }^{1}$ P1: Estimated average canopy height after the growing season in 2015. P2: Estimated average canopy height after the growing season in 2016. ${ }^{2}$ P1: Simulated maximum LAI in 2013 based on measured height and diameter. P2: Measured maximum LAI in 2016. ${ }^{3}$ Taken from SGU [48]. ${ }^{4}$ Total number of treatments during the rotation cycle. ${ }^{5}$ Yield after four growing years.

\subsection{Experimental Setup}

Measurements were done with two different setups. First, we used a branch chamber (volume ca $13 \mathrm{~L}$ ) during repeated campaigns throughout the growing seasons 2015 and 2016. The aim of this setup was to follow the seasonal pattern of BVOC emissions during the two growing seasons.

Second, a photosynthesis system with a leaf chamber $\left(6 \mathrm{~cm}^{2}\right.$ leaf area) was used to provide photosynthesis information in parallel to BVOC measurements focusing on the light response.

\subsubsection{Branch Chamber Setup}

The branch chamber used was a cylindrical construction made of PFA and stainless steel covered with a thin transparent PFA film [49-51]. At the beginning of each campaign, the tip (ca $30 \mathrm{~cm}$ long) of a shoot from one Salix tree was carefully inserted into the chamber the day before measurements started, avoiding any disturbance of the leaves. The chamber was left open on one end when not in use (i.e., during night). Every day before the measurements started, the chamber lid was closed, and the chamber was flushed with purge air for one hour. After this procedure, the branch chamber was used as a dynamic chamber with a continuous purge flow of 3-4 $1 \times \mathrm{min}^{-1}$, leading to a residence time of ca $4 \mathrm{~min}$ for the air within the chamber.

In 2015, only one branch chamber was used. Starting in June 2016, two identical sets of branch chambers were used in parallel at different canopy heights. Each campaign, two trees standing next to each other were chosen for the branch chamber measurements. Prevailing conditions of temperature $\left(\mathrm{T},{ }^{\circ} \mathrm{C}\right)$ and relative humidity $(\mathrm{RH})$ were measured both inside and outside the branch chamber (CS215, Campbell Scientific, UT, USA). Pho- 
tosynthetically active radiation (PAR, $\mu \mathrm{mol} \mathrm{m} \mathrm{m}^{-2} \mathrm{~s}^{-1}$ ) was measured close to the chamber and at canopy level (Li-190, LI-COR, Lincoln, NE, USA). The data were recorded on a data logger (CR1000, Campbell Scientific, Logan, UT, USA) every $10 \mathrm{sec}$ and stored as 1 min averages.

\subsubsection{Light Response Curves and Photosynthesis Rates}

Besides the branch chamber, a portable photosynthesis system (LI-6400XT, LI-COR, NE, USA) was used in 2016 to provide photosynthesis information in parallel with BVOC measurements from individual Salix leaves $[42,46,50,52]$. The leaf chamber has a capacity to measure leaves with an area up to $6 \mathrm{~cm}^{2}\left(2 \times 3 \mathrm{~cm}^{2}\right)$ and the measurements were done on the middle part of the leaves to obtain the maximum area of the leaves. The flow rate into the leaf chamber was set to $500 \mu \mathrm{mol} \mathrm{s}^{-1}\left(\mathrm{ca} 0.7 \mathrm{~L} \mathrm{~min}^{-1}\right.$ ). The leaf chamber was equipped with a LED source (6400-02B). This photosynthesis system made it possible to control the PAR, T, $\mathrm{RH}$, and carbon dioxide $\left(\mathrm{CO}_{2}\right)$ concentration within the leaf chamber. Temperature and $\mathrm{CO}_{2}$ were set to ambient conditions $\left(20-25^{\circ} \mathrm{C}\right.$ and $\left.400 \mathrm{ppm}\right)$, while PAR was set to increase between 0 and $1500 \mu \mathrm{mol} \mathrm{m}^{-2} \mathrm{~s}^{-1}$ in six steps $(0,150,300,450,600,1000$, and $1500 \mu \mathrm{mol} \mathrm{m}^{-2} \mathrm{~s}^{-1}$ ) to obtain light response curves. Relative humidity was regulated to match ambient values and ranged mainly from $30 \%$ to $70 \%$. Net assimilation rate (A, $\mu \mathrm{mol} \mathrm{CO} \mathrm{CO}_{2} \mathrm{~m}^{-2} \mathrm{~s}^{-1}$ ), transpiration $\left(\mathrm{Tr}, \mathrm{mmol} \mathrm{H}_{2} \mathrm{O} \mathrm{m}^{-2} \mathrm{~s}^{-1}\right.$ ), and stomatal conductance $\left(\mathrm{g}_{\mathrm{s}}, \mathrm{mol} \mathrm{H}_{2} \mathrm{O} \mathrm{m}^{-2} \mathrm{~s}^{-1}\right.$ ) were measured with the Li-6400XT, and water use efficiency (WUE, mmol CO$~_{2}$ mol $^{-1} \mathrm{H}_{2} \mathrm{O}$ ) was then calculated by dividing A by Tr.

\subsection{BVOC Sampling}

BVOC sampling was based on adsorbent cartridges containing Tenax TA (a porous organic polymer) and Carbograph 1TD (graphitized black carbon (C)) (Markes International Ltd., Mid Glamorgan, UK). Prior to sampling, all cartridges were conditioned. In this process, $\mathrm{N}_{2}$ is used as a carrier gas while the cartridges are heated up to $300{ }^{\circ} \mathrm{C}$, which empty the cartridges from possible contamination.

Air from the dynamic chamber was pulled through an adsorbent cartridge for $20 \mathrm{~min}$ per sample at a flow rate of $200 \mathrm{~mL} \mathrm{~min}^{-1}$ using a flow-controlled pump (Pocket Pump, SKC Ltd., Dorset, UK), leading to a total sample volume of $4 \mathrm{~L}$. In the case of the leaf chamber, the photosynthesis system had been modified with a trace-gas tube connection after the outlet of the leaf chamber $[42,46,50,52]$. This way, BVOC samples could be taken in parallel to the on-going photosynthesis measurements.

To provide VOC-free and $\mathrm{O}_{3}$-free air into the branch chamber, air entering the branch chamber was passed through a hydrocarbon trap (Alltech, Associates Inc., Chicago, IL, USA), which contained activated $\mathrm{C}$ and a $\mathrm{MnO}_{2}$-coated copper mesh. The hydrocarbon trap was also attached to the intake of the photosynthesis system. For the branch chamber, background samples of the purge air entering the chamber were taken every day, while blank samples from the empty leaf chamber were taken after the last light intensity $\left(1500 \mu \mathrm{mol} \mathrm{m}^{-2} \mathrm{~s}^{-1}\right)$ measurement.

During the campaigns, BVOC samples were taken during day time (8:00-18:00). In the case of the leaf chamber, measurements started one hour after the leaf was inserted to avoid potential stress-induced BVOCs from physical handling [42,52]. When a new light level was set, 30 min passed before the BVOC sampling started so the leaf had time to adapt to the new condition [52]. After sampling, the cartridges were sealed with Teflon-coated brass caps and stored at $3{ }^{\circ} \mathrm{C}$ until analysis. After each campaign was finished, the sampled leaves were harvested and dried at $75{ }^{\circ} \mathrm{C}$ for two days to measure the dry weight.

In total, 754 samples were taken on 35 trees during 15 campaigns between July 2015 and October 2016, and the campaigns were in general 2-5 days (Table 2). Due to setup and instrumental failure, 26 samples were missing in 2015 and 65 in 2016. Campaigns performed in 2015 were all on P1 except the last one in September, where the first day was on P1 (P1* in Table 2, the star means another variety) and the last two days were on P2. This change was due to a rust outbreak of a fungi (Melampsora spp.). Signs of 
the infestation were seen in July, and by mid-September most of the trees had shed their leaves (Figure S2). Leaves with the least damage were chosen, but more or less all trees were equally affected. All the campaigns performed in 2016 were done at P2. No signs of Melampsora were observed on Tora but leaf-feeding beetles (Phratora vulgatissima) damaged the leaves, especially higher up in the canopy. On account of P. vulgatissima, undamaged leaves were hard to find, at least in the uppermost part of the canopy, from July onward (Figure S3).

Table 2. All campaigns done in 2015 and 2016 with branch and leaf chambers. Two different plantations (P1 and P2) were studied and new trees were studied each campaign. The star $\left(\mathrm{P}^{*}\right)$ means that another variety was measured at this site compared with the rest of the campaigns on P1. Height levels were $\mathrm{z}_{\mathrm{L}}$ (up to ca $70 \%$ of the total canopy height (TCH)), $\mathrm{z}_{\mathrm{M}}$ (up to ca $70 \%$ of the TCH but growing at the edge of the plantation), and $\mathrm{z}_{\mathrm{H}}$ (heights above $\mathrm{z}_{\mathrm{L}}$ ). $\mathrm{z} / \mathrm{H}$ means the ratio between the measured leaves $(\mathrm{z})$ and the canopy height $(\mathrm{H})$.

\begin{tabular}{|c|c|c|c|c|c|c|}
\hline \multicolumn{7}{|c|}{ Branch Chamber } \\
\hline $\begin{array}{c}\text { Campaign } \\
\text { No. }\end{array}$ & Time & $\begin{array}{c}\text { Relative Canopy } \\
\text { Height }(\mathrm{z} / \mathrm{H})\end{array}$ & Height Group & Samples & Trees & Plantation \\
\hline 1 & 2015: 16-17 July & 1.00 & $\mathrm{z}_{\mathrm{H}}$ & 8 & 1 & P1 \\
\hline 2 & 2015: 28-31 July & 1.00 & $\mathrm{z}_{\mathrm{H}}$ & 30 & 1 & P1 \\
\hline 3 & 2015: 4-7 Aug. & 1.00 & $\mathrm{Z}_{\mathrm{H}}$ & 28 & 1 & P1 \\
\hline 4 & 2015: 18-21 Aug. & 1.00 & $\mathrm{Z}_{\mathrm{H}}$ & 31 & 1 & P1 \\
\hline 5 & 2015: 1-4 Sep. & 0.85 & $\mathrm{z}_{\mathrm{H}}$ & 31 & 1 & P1 \\
\hline \multirow[t]{2}{*}{6} & 2015: 8 and 10-11 Sep. & $0.35 ; 0.80$ & $\mathrm{z}_{\mathrm{M}} ; \mathrm{z}_{\mathrm{H}}$ & $4 ; 10$ & 2 & $\mathrm{P} 1 *$ \& 2 \\
\hline & & & & Tot: 142 & Tot: 7 & \\
\hline \multicolumn{7}{|c|}{ Branch Chamber } \\
\hline $\begin{array}{c}\text { Campaign } \\
\text { No. }\end{array}$ & Time & $\begin{array}{l}\text { Relative Canopy } \\
\text { Height }(\mathrm{z} / \mathrm{H})\end{array}$ & Height Group & Samples & Trees & Plantation \\
\hline 1 & 2016: 4-5 May & 0.40 & $\mathrm{z}_{\mathrm{M}}$ & 14 & 1 & $\mathrm{P} 2$ \\
\hline 2 & 2016: 24 May & 0.75 & $\mathrm{z}_{\mathrm{H}}$ & 6 & 1 & $\mathrm{P} 2$ \\
\hline 3 & 2016: 6-10 June & $0.30 ; 0.75$ & $\mathrm{Z}_{\mathrm{M}} ; \mathrm{z}_{\mathrm{H}}$ & $39 ; 10$ & 2 & $\mathrm{P} 2$ \\
\hline 4 & 2016: 19-23 June & $0.30 ; 0.75$ & $\mathrm{Z}_{\mathrm{M}} ; \mathrm{z}_{\mathrm{H}}$ & $39 ; 40$ & 2 & $\mathrm{P} 2$ \\
\hline 5 & 2016: 11-15 July & $0.30 ; 0.80$ & $\mathrm{Z}_{\mathrm{M}} ; \mathrm{z}_{\mathrm{H}}$ & $36 ; 36$ & 2 & $\mathrm{P} 2$ \\
\hline 6 & 2016: 26-29 July & $0.70 ; 0.90$ & $\mathrm{z}_{\mathrm{M}} ; \mathrm{z}_{\mathrm{H}}$ & $32 ; 30$ & 2 & $\mathrm{P} 2$ \\
\hline 7 & 2016: 15-17 Aug. & $0.55 ; 0.90$ & $\mathrm{Z}_{\mathrm{M}} ; \mathrm{z}_{\mathrm{H}}$ & $20 ; 12$ & 2 & $\mathrm{P} 2$ \\
\hline 8 & 2016: 6-9 Sep. & $0.65 ; 0.90$ & $\mathrm{Z}_{\mathrm{M}} ; \mathrm{z}_{\mathrm{H}}$ & $30 ; 28$ & 2 & $\mathrm{P} 2$ \\
\hline \multirow[t]{2}{*}{9} & 2016: 10-13 Oct. & $0.50 ; 0.95$ & $\mathrm{z}_{\mathrm{M}} ; \mathrm{z}_{\mathrm{H}}$ & $29 ; 26$ & 2 & $\mathrm{P} 2$ \\
\hline & & & & Tot: 427 & Tot: 16 & \\
\hline \multicolumn{7}{|c|}{ Leaf Chamber } \\
\hline $\begin{array}{c}\text { Campaign } \\
\text { No. }\end{array}$ & Time & $\begin{array}{l}\text { Relative Canopy } \\
\text { Height (z/H) }\end{array}$ & Height Group & Samples & Trees & Plantation \\
\hline 5 & 2016: 11-15 July & $0.15 ; 0.15 ; 0.40$ & $\mathrm{z}_{\mathrm{M}} ; \mathrm{z}_{\mathrm{M}} ; \mathrm{z}_{\mathrm{M}}$ & $7 ; 7 ; 4$ & 3 & $\mathrm{P} 2$ \\
\hline 6 & 2016: 26-29 July & $0.15 ; 0.60 ; 0.80 ; 0.80$ & $\mathrm{z}_{\mathrm{M}} ; \mathrm{z}_{\mathrm{L}} ; \mathrm{z}_{\mathrm{H}} ; \mathrm{z}_{\mathrm{H}}$ & $7 ; 7 ; 7 ; 7$ & 3 & $\mathrm{P} 2$ \\
\hline 7 & 2016: 15-17 Aug. & $0.20 ; 0.65 ; 0.90$ & $\mathrm{z}_{\mathrm{M}} ; \mathrm{z}_{\mathrm{L}} ; \mathrm{z}_{\mathrm{H}}$ & $6 ; 7 ; 7$ & 3 & $\mathrm{P} 2$ \\
\hline \multirow[t]{2}{*}{8} & 2016: 6-9 Sep. & $0.65 ; 0.20 ; 0.95 ; 0.95$ & $\mathrm{z}_{\mathrm{L}} ; \mathrm{z}_{\mathrm{M}} ; \mathrm{z}_{\mathrm{H}} ; \mathrm{z}_{\mathrm{H}}$ & $7 ; 7 ; 7 ; 7$ & 3 & $\mathrm{P} 2$ \\
\hline & & & & Tot: 94 & Tot: 12 & \\
\hline
\end{tabular}

The heights of the measurements were divided into three categories. The lower height $\left(\mathrm{z}_{\mathrm{L}}\right.$ ) included leaves that were below or in the lower part of canopy (up to ca $70 \%$ of the total canopy height $(\mathrm{TCH})$ ) and growing within the plantation. The higher height $\left(\mathrm{z}_{\mathrm{H}}\right)$ included leaves above $\mathrm{z}_{\mathrm{L}}(>70 \%$ of $\mathrm{TCH})$ and growing in a more sun-adapted environment compared with the shade-adapted leaves in $\mathrm{z}_{\mathrm{L}}$. Trees growing at the edge that were $<70 \%$ of the $\mathrm{TCH}$ were classified as middle $\left(\mathrm{z}_{\mathrm{M}}\right)$ because they were expected to be more sunlit than if they grew within the plantation. The canopy height $(\mathrm{H})$ was measured as the average height for the trees that were growing just next to the leaves, which the BVOC 
emissions were measured from, as these trees were responsible for the light conditions at the measured leaves. All measurements during 2015 were done on $\mathrm{z}_{\mathrm{H}}$ except for the last campaign. Measurements with the branch chambers in 2016 were done at the edge of P2, while the measurements with the leaf chamber were done both on the edge and within P2.

\subsection{Gas Chromatography-Mass Spectrometry and Data Processing}

All samples were analyzed by thermal desorption (UNITY2 thermal desorber, Markes International Ltd., Mid Glamorgan, UK) in combination with an ULTRA autosampler and gas chromatograph-mass spectrometer (GC-MS) (7890A Series GC coupled with a 5975C inert MSD/DS Performance Turbo EI System, Agilent, CA, USA) [42,53]. Separation of BVOCs was done by a HP-5 capillary column $(50 \mathrm{~m} \times 0.2 \mathrm{~mm}$, film thickness $0.33 \mu \mathrm{m})$ and helium was used as a carrier gas. The oven temperature started at $40{ }^{\circ} \mathrm{C}$ for $1 \mathrm{~min}$, was first raised to $210{ }^{\circ} \mathrm{C}$ with a rate of $5^{\circ} \mathrm{C} \mathrm{min}-1$, and was then raised to $250{ }^{\circ} \mathrm{C}$ with a rate of $20^{\circ} \mathrm{C} \mathrm{min}^{-1}$. The compounds were analyzed in the program Enhanced ChemStation (MSD ChemStation E.02.01.1177, Copyright 1989-2010 Agilent Technologies, Inc. Santa Clara, CA, USA) and identified by injected external standards (Table S1) or according to mass spectra in the NIST 8.0 database. To quantify BVOCs for which no specific standard was available, $\alpha$-pinene was used for monoterpenes (MTs), humulene for sesquiterpenes (SQTs), and toluene for other VOCs. Only sample peaks that had at least twice as strong a signal as the corresponding peaks in background samples were chosen for further analysis.

Two compounds, toluene and butylated hydroxytoluene, were removed from all measurements done by LI-6400XT because they had approximately the same concentration in the background samples as the measurements from the leaves and were therefore assumed to be emitted by this instrument.

The emission rates for the BVOCs were calculated by Equation (1), according to Ortega and Helmig [54]

$$
E=\left(C_{2}-C_{1}\right) \times Q \times m^{-1} .
$$

where $E\left(\mu g g_{d w}{ }^{-1} h^{-1}\right)$ is the emission rate, $C_{2}\left(\mu g \mathrm{~L}^{-1}\right)$ is the BVOC concentration taken from the chamber, $C_{1}\left(\mu \mathrm{g} \mathrm{L}^{-1}\right)$ is the BVOC concentration entering the branch chamber or the BVOC concentration inside the empty leaf chamber, $Q\left(\mathrm{~L} \mathrm{~h}^{-1}\right)$ is the flow rate of the purge air, and $m\left(\mathrm{~g}_{\mathrm{dw}}\right)$ is the dried mass of the leaves contained in the chamber.

A standardization for BVOCs that were both light and temperature dependent was done by Equation (2) according to Guenther et al. [55]. The reason for this standardization was to allow for comparison with other studies, regardless of prevailing environmental conditions. The STD values for T and PAR were $303.15 \mathrm{~K}$ and $1000 \mu \mathrm{mol} \mathrm{m}{ }^{-2} \mathrm{~s}^{-1}$, respectively. The compounds that were STD with Equation (2) were isoprene, ocimene, and $\alpha$-farnesene.

$$
E=E_{S} \times C_{T} \times C_{L}
$$

where $E\left(\mu \mathrm{g} \mathrm{g}_{\mathrm{dw}}{ }^{-1} \mathrm{~h}^{-1}\right)$ is the actual emission at the measured chamber temperature $T$ $(\mathrm{K})$ and PAR ( $\left.\mu \mathrm{mol} \mathrm{m} \mathrm{m}^{-2} \mathrm{~s}^{-1}\right), E_{S}$ is the STD emission, and $C_{T}$ and $C_{L}$ are dimensionless correction factors for temperature and light defined by Equations (3) and (4).

$$
C_{L}=\frac{\alpha C_{L 1} P A R}{\sqrt{1+\alpha^{2} P A R^{2}}}
$$

where $\alpha(=0.0027)$ and $C_{L 1}(=1.066)$ are empirical coefficients taken from Guenther et al. [55]

$$
C_{T}=\frac{\exp \frac{C_{T 1}\left(T-T_{s}\right)}{R T_{s} T}}{1+\exp \frac{C_{T 2}\left(T-T_{M}\right)}{R T_{s} T}}
$$

where $C_{T 1}\left(=95,000 \mathrm{~J} \mathrm{~mol}^{-1}\right), C_{T 2}\left(=230,000 \mathrm{~J} \mathrm{~mol}^{-1}\right)$, and $T_{M}(=314 \mathrm{~K})$ are empirical coefficients [55]. $R\left(=8.314 \mathrm{~J} \mathrm{~K}^{-1} \mathrm{~mol}^{-1}\right)$ is the universal gas constant and $T_{\mathcal{S}}(=303.15 \mathrm{~K})$ is the standard temperature. 
For compounds that are temperature, but not light, dependent, the STD emission can be calculated with the temperature-dependent Equation (5), which was used on all terpenoids except isoprene, ocimene, and $\alpha$-farnesene.

$$
E=E_{S} \times e^{\beta\left(T-T_{S}\right)}
$$

where $E$ is the actual emission rate $\left(\mu g \mathrm{~g}_{\mathrm{dw}}{ }^{-1} \mathrm{~h}^{-1}\right)$ at temperature $T(\mathrm{~K}), E_{s}\left(\mu \mathrm{g} \mathrm{g}_{\mathrm{dw}}{ }^{-1} \mathrm{~h}^{-1}\right)$ is the STD emission rate at the standard temperature $T_{\mathcal{S}}(=303.15 \mathrm{~K})$, and $\beta\left(=0.09 \mathrm{~K}^{-1}\right.$ for MTs and $0.17 \mathrm{~K}^{-1}$ for SQTs) is an empirical constant $[55,56]$.

Fitted net assimilation curves were done by using Smith's equation, Equation (6) [57]

$$
A=\frac{\alpha_{A} P A R}{\sqrt{1+\frac{\alpha_{A}^{2} P A R^{2}}{A_{\max }^{2}}}}-A_{d}
$$

where $A$ is net assimilation $\left(\mu \mathrm{mol} \mathrm{CO} \mathrm{Cm}^{-2} \mathrm{~s}^{-1}\right), \alpha_{A}$ is the initial quantum yield $\left(\mathrm{mol} \mathrm{mol}^{-1}\right)$, $A_{d}$ is dark respiration $\left(\mu \mathrm{mol} \mathrm{CO}_{2} \mathrm{~m}^{-2} \mathrm{~s}^{-1}\right)$, and $A_{\text {max }}$ is net assimilation at the maximum PAR (1500 $\left.\mu \mathrm{mol} \mathrm{m} \mathrm{m}^{-2} \mathrm{~s}^{-1}\right)$.

The statistical tests were performed with a Kruskal-Wallis test at a significance level of 0.05 when comparing emissions between different heights since the data did not have a Gaussian distribution. The optimized parameters for the fitted light response curves were determined by minimizing the difference between measured and simulated emissions according to a root mean square procedure.

\section{Results}

\subsection{BVOC Emissions from Salix}

The total number of detected peaks found during GC-MS analysis was 39 (Table S2), whereof 37 could be identified and the remaining were named as unknown. The average total BVOC emission from all measurements in 2015 and 2016 was $24.4( \pm 5.8$, standard deviation (SD)) $\mu \mathrm{g} \mathrm{g}_{\mathrm{dw}}{ }^{-1} \mathrm{~h}^{-1}$. Isoprene made up more than $96 \%$ of the total emission and had an average emission rate of $23.5( \pm 28.1) \mathrm{\mu g} \mathrm{g}_{\mathrm{dw}}{ }^{-1} \mathrm{~h}^{-1}$ (Table 3). The corresponding STD isoprene emission rate was $45.2( \pm 42.9) \mathrm{Mg} \mathrm{g}_{\mathrm{dw}}{ }^{-1} \mathrm{~h}^{-1}$.

The average MT emission rate was $0.163( \pm 0.117) \mu \mathrm{g} \mathrm{g}_{\mathrm{dw}}{ }^{-1} \mathrm{~h}^{-1}$, which was $0.7 \%$ of the total BVOC emission. Nine MTs were detected: allo-ocimene, $\alpha$-pinene, eucalyptol, limonene, linalool, myrcene, ocimene, p-cymene, and 3-carene. Except in October, ocimene was the dominant MT $\left(0.137 \pm 0.321 \mu \mathrm{g} \mathrm{g} \mathrm{dw}^{-1} \mathrm{~h}^{-1}\right)$ and more than 17 times higher than the second most emitted MT, which was limonene $\left(0.008 \pm 0.042 \mu \mathrm{g} \mathrm{g}_{\mathrm{dw}}{ }^{-1} \mathrm{~h}^{-1}\right)$. The total STD MT emission rate was $0.301( \pm 0.201) \mu g \mathrm{~g}_{\mathrm{dw}}{ }^{-1} \mathrm{~h}^{-1}$. The group with the lowest emission rate among the terpenoids was SQTs with an average emission of $0.035( \pm 0.062) \mu \mathrm{g} \mathrm{g}_{\mathrm{dw}}{ }^{-1} \mathrm{~h}^{-1}$, which resulted in a contribution of ca $0.1 \%$ to the total average BVOC emission. Four SQTs were observed: $\alpha$-farnesene, caryophyllene, humulene, and nerolidol. The highest average emission rates were seen for caryophyllene $\left(0.011 \pm 0.031 \mu \mathrm{g} \mathrm{g}_{\mathrm{dw}}{ }^{-1} \mathrm{~h}^{-1}\right)$ and humulene $\left(0.010 \pm 0.090 \mu \mathrm{g} \mathrm{g}_{\mathrm{dw}}{ }^{-1} \mathrm{~h}^{-1}\right)$. The average STD emission of SQTs was $0.103( \pm 0.249) \mu \mathrm{g} \mathrm{g}_{\mathrm{dw}}{ }^{-1} \mathrm{~h}^{-1}$.

Non-terpenoid compounds were grouped as other VOCs and their classification can be seen in Tables 3 and S2. The most abundant among the identified other VOCs were cyclopentenyl acetylene $\left(0.083 \pm 0.205 \mu \mathrm{g} \mathrm{g}_{\mathrm{dw}}{ }^{-1} \mathrm{~h}^{-1}\right)$, benzaldehyde $\left(0.065 \pm 0.163 \mu \mathrm{g} \mathrm{g} \mathrm{dw}^{-1} \mathrm{~h}^{-1}\right)$, hexanal $\left(0.064 \pm 0.320 \mu \mathrm{g} \mathrm{g}_{\mathrm{dw}}{ }^{-1} \mathrm{~h}^{-1}\right)$, nonanal $\left(0.061 \pm 0.147 \mu \mathrm{g} \mathrm{g}_{\mathrm{dw}}{ }^{-1} \mathrm{~h}^{-1}\right)$, and 2-ethylhexanoic acid $\left(0.059 \pm 0.252 \mu \mathrm{g} \mathrm{g}_{\mathrm{dw}}{ }^{-1} \mathrm{~h}^{-1}\right)$. 
Table 3. Average measured (E) and standardized $\left(E_{S}\right)$ emission rates ( $\mu g g_{d w}{ }^{-1} h^{-1}, n=663$ ) from all measurements for the most abundant biogenic volatile organic compounds (BVOCs) in each group. Numbers in parentheses are standard deviation (SD, $\mu \mathrm{g} \mathrm{g}_{\mathrm{dw}}{ }^{-1} \mathrm{~h}^{-1}$ ). No standardization was made for other VOCs $(-)$.

\begin{tabular}{|c|c|c|}
\hline BVOC & $E\left(\mu g g_{d w}{ }^{-1} h^{-1}\right)$ & $E_{S}\left(\mu g g_{d w}{ }^{-1} h^{-1}\right)$ \\
\hline isoprene & $23.5(28.1)$ & $45.2(42.9)$ \\
\hline Total MTs & $0.163(0.117)$ & $0.301(0.201)$ \\
\hline ocimene & $0.137(0.321)$ & $0.255(0.540)$ \\
\hline limonene * & $0.008(0.042)$ & $0.014(0.081)$ \\
\hline p-cymene & $0.006(0.042)$ & $0.011(0.069)$ \\
\hline linalool & $0.006(0.017)$ & $0.010(0.035)$ \\
\hline$\alpha$-pinene & $0.003(0.021)$ & $0.005(0.034)$ \\
\hline 3-carene * & $0.002(0.019)$ & $0.004(0.040)$ \\
\hline Total SQTs & $0.035(0.062)$ & $0.103(0.249)$ \\
\hline caryophellene $^{\dagger}$ & $0.011(0.031)$ & $0.024(0.080)$ \\
\hline humulene & $0.010(0.090)$ & $0.040(0.409)$ \\
\hline$\alpha$-farnesene ${ }^{\dagger}$ & $0.009(0.062)$ & $0.017(0.125)$ \\
\hline Total other VOCs & $0.751(0.159)$ & - \\
\hline cyclopentyl acetylene $\S$ & $0.083(0.205)$ & - \\
\hline benzaldehyde (benzenoid) & $0.065(0.163)$ & - \\
\hline hexanal (aldehyde) & $0.064(0.320)$ & - \\
\hline nonanal (aldehyde) & $0.061(0.147)$ & - \\
\hline 2-ethylhexanoic acid ${ }^{\S}$ (carboxylic acid) & $0.059(0.252)$ & - \\
\hline pentanal $\S$ (aldehyde) & $0.037(0.226)$ & - \\
\hline decanal ${ }^{\S}$ (aldehyde) & $0.036(0.148)$ & - \\
\hline octanal (aldehyde) & $0.030(0.105)$ & - \\
\hline 2-methylbutane $\S$ (alkane) & $0.027(0.105)$ & - \\
\hline 2-pentanone $\S$ (ketone) & $0.026(0.208)$ & - \\
\hline
\end{tabular}

* These MTs were quantified with $\alpha$-pinene as the injected standard in GC-MS. ${ }^{+}$These SQTs were quantified with humulene as the injected

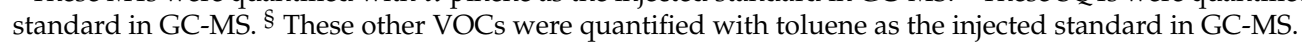

\subsection{Seasonality of BVOC Emissions Measured with Branch Chambers}

\subsubsection{Isoprene}

The emission rates for isoprene changed mostly according to prevailing $\mathrm{T}$ and PAR values. The average STD isoprene emission from P1 in 2015 was $59.3( \pm 44.5) \mu \mathrm{g} \mathrm{g}_{\mathrm{dw}}{ }^{-1} \mathrm{~h}^{-1}$, where the corresponding average chamber $\mathrm{T}\left(\mathrm{T}_{\mathrm{C}}\right)$ and chamber PAR $\left(\mathrm{PAR}_{\mathrm{C}}\right)$ were $24.9( \pm 5.4)^{\circ} \mathrm{C}$ and $462( \pm 296) \mu \mathrm{mol} \mathrm{m}^{-2} \mathrm{~s}^{-1}$, respectively. Most of the measured isoprene emissions that varied between 92.0 and $153.2 \mu \mathrm{g} \mathrm{g}_{\mathrm{dw}}{ }^{-1} \mathrm{~h}^{-1}$ during 2015 occurred in the middle of July and during the second half of August. The chamber T was high $\left(>27.5^{\circ} \mathrm{C}\right)$ and $\mathrm{PAR}_{\mathrm{C}}$ varied from 304 to $1654 \mu \mathrm{mol} \mathrm{m}^{-2} \mathrm{~s}^{-1}$ for these isoprene emissions (Figure 1A-C). The measured emission peaked $\left(153.2 \mu \mathrm{g} \mathrm{g}_{\mathrm{dw}}{ }^{-1} \mathrm{~h}^{-1}\right)$ in July and the STD emission peaked $\left(177.6 \mu \mathrm{g} \mathrm{g}_{\mathrm{dw}}{ }^{-1} \mathrm{~h}^{-1}\right)$ in August 2015.

With more unsteady weather conditions and under cloudy conditions and even rain, low emissions of isoprene (1.6-7.0 $\left.\mu \mathrm{g} \mathrm{g}_{\mathrm{dw}}{ }^{-1} \mathrm{~h}^{-1}\right)$ were observed even during the peak growing season in July and August 2015 due to low PARc values $\left(<200 \mu \mathrm{mol} \mathrm{m}^{-2} \mathrm{~s}^{-1}\right)$. In particular, in the beginning of September when Tc was $<15^{\circ} \mathrm{C}$ and PARc was $<160 \mu \mathrm{mol}$ $\mathrm{m}^{-2} \mathrm{~s}^{-1}$, the emission rates only reached up to $0.1 \mu \mathrm{g} \mathrm{g} \mathrm{dw}^{-1} \mathrm{~h}^{-1}$. In addition, the leaves were damaged in September due to the infestation of Melampsora on P1.

The seasonal trend for measured and STD isoprene emissions in 2016 showed an increase from spring to summer; thereafter, it decreased from late summer to mid-autumn. The average STD isoprene emission in 2016 was $30.6( \pm 26.7) \mu \mathrm{g} \mathrm{g}_{\mathrm{dw}}{ }^{-1} \mathrm{~h}^{-1}$ and the average $T_{C}$ and PAR $_{C}$ were $23.2( \pm 7.6){ }^{\circ} \mathrm{C}$ and $521( \pm 444) \mu \mathrm{mol} \mathrm{m}^{-2} \mathrm{~s}^{-1}$. The measured isoprene emission varied from 50.1 to $143.7 \mu \mathrm{g} \mathrm{g}_{\mathrm{dw}}{ }^{-1} \mathrm{~h}^{-1}$ between June and August but 
emissions up to $46.5 \mu \mathrm{g} \mathrm{g}_{\mathrm{dw}}{ }^{-1} \mathrm{~h}^{-1}$ were already observed in May (Figure 2C). All measured isoprene emission rates $>50 \mu \mathrm{g} \mathrm{g}_{\mathrm{dw}}{ }^{-1} \mathrm{~h}^{-1}$ in $2016 \mathrm{had}$ corresponding $\mathrm{T}_{\mathrm{C}}$ and $\mathrm{PAR}_{\mathrm{C}}$ ranging from 26.8 to $39.9^{\circ} \mathrm{C}$ and from 365 to $1518 \mu \mathrm{mol} \mathrm{m}{ }^{-2} \mathrm{~s}^{-1}$. The STD isoprene emission peaked (150.0 $\left.\mathrm{gg} \mathrm{g}_{\mathrm{dw}^{-1}} \mathrm{~h}^{-1}\right)$ in late July 2016, while the measured isoprene emission peaked (143.7 $\left.\mathrm{g} \mathrm{g} \mathrm{g} \mathrm{dw}^{-1} \mathrm{~h}^{-1}\right)$ in August. Isoprene emissions were negligible during the last campaign in October, when $\mathrm{T}_{\mathrm{C}}$ and $\mathrm{PAR}_{\mathrm{C}}$ were low (less than $11{ }^{\circ} \mathrm{C}$ and $110 \mu \mathrm{mol} \mathrm{m}{ }^{-2} \mathrm{~s}^{-1}$, respectively).

The influence of $\mathrm{T}_{\mathrm{C}}$ on the isoprene emission rates showed a stronger exponential increase for the variety on P1 than for Tora on P2 (Figure 3). In particular, when $\mathrm{T}_{\mathrm{C}}$ reached above $23{ }^{\circ} \mathrm{C}$, the average emission in 2015 increased faster than during 2016. The steeper response in 2015 was possibly due to the fact that this variety was a stronger emitter of isoprene, but the unexpected lower average emission when $\mathrm{T}_{\mathrm{C}}$ varied from 30 to $36^{\circ} \mathrm{C}$ in 2016 also reduced the slope of the fitted curve this year.

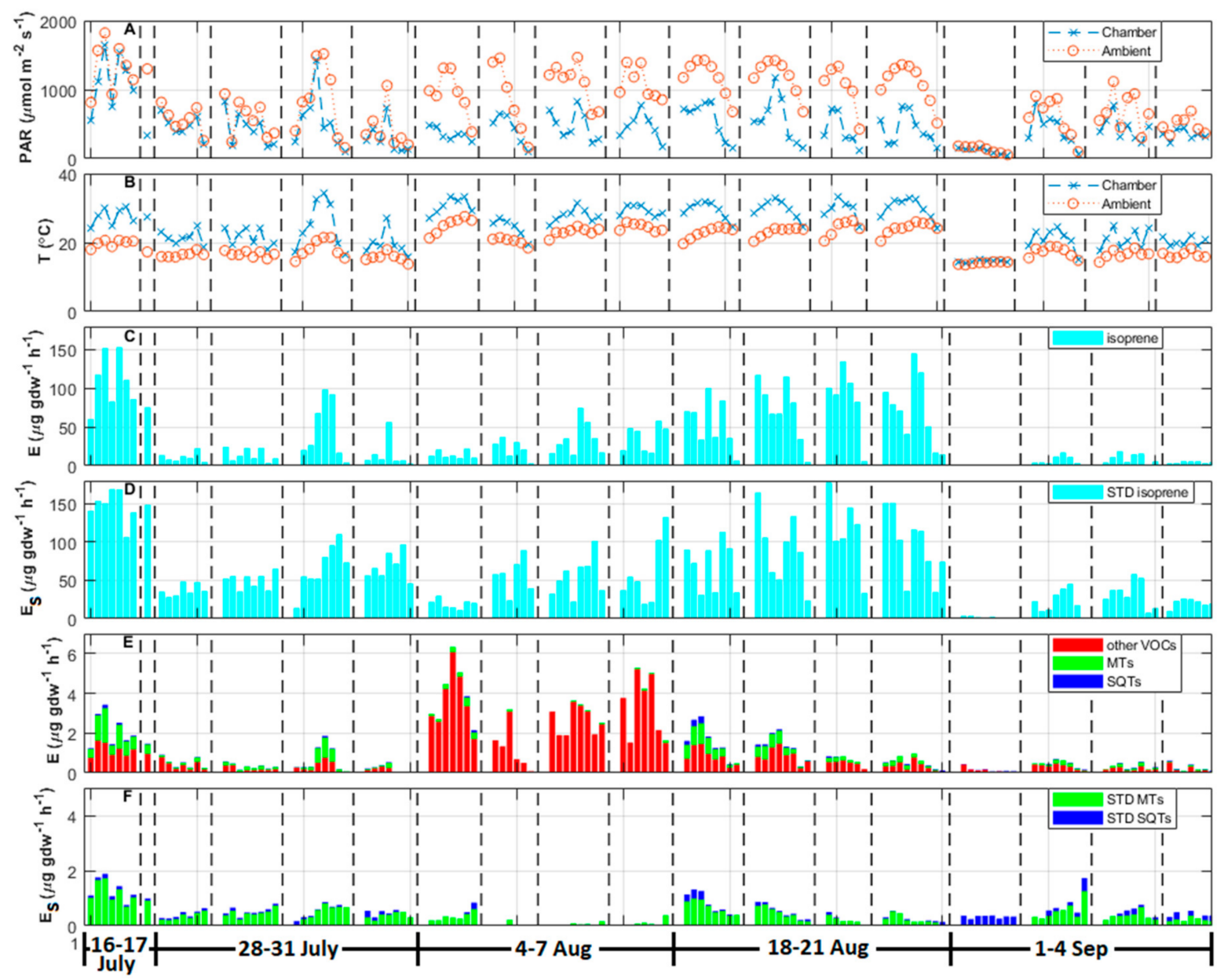

Figure 1. Measurements from P1 in 2015. (A) Photosynthetically active radiation (PAR, $\mu \mathrm{mol} \mathrm{m}^{-2} \mathrm{~s}^{-1}$ ) values for chamber condition $\left(\mathrm{PAR}_{\mathrm{C}}\right.$, blue cross and dashed line) and ambient condition (red circle and dotted line). (B) Temperature $\left({ }^{\circ} \mathrm{C}\right)$ values for chamber condition $\left(\mathrm{T}_{\mathrm{C}}\right.$, blue cross and dashed line) and ambient condition (red circle and dotted line). (C) Emission rates $\left(\mu \mathrm{g} \mathrm{g}_{\mathrm{dw}}{ }^{-1} \mathrm{~h}^{-1}\right)$ for isoprene (cyan). (D) Standardized (STD) emission rates $\left(\mu \mathrm{g} \mathrm{g}_{\mathrm{dw}}{ }^{-1} \mathrm{~h}^{-1}\right)$ for isoprene (cyan). (E) Emission rates ( $\mu \mathrm{g} \mathrm{g}_{\mathrm{dw}}{ }^{-1} \mathrm{~h}^{-1}$ ) of other VOCs (red), monoterpenes (MTs, green), and sesquiterpenes (SQTs, blue). (F) STD emission rates $\left(\mu \mathrm{g} \mathrm{g}_{\mathrm{dw}}{ }^{-1} \mathrm{~h}^{-1}\right)$ for MTs (green) and SQTs (blue). Vertical dashed lines separate the different days. Each bar represents individual measurements. 


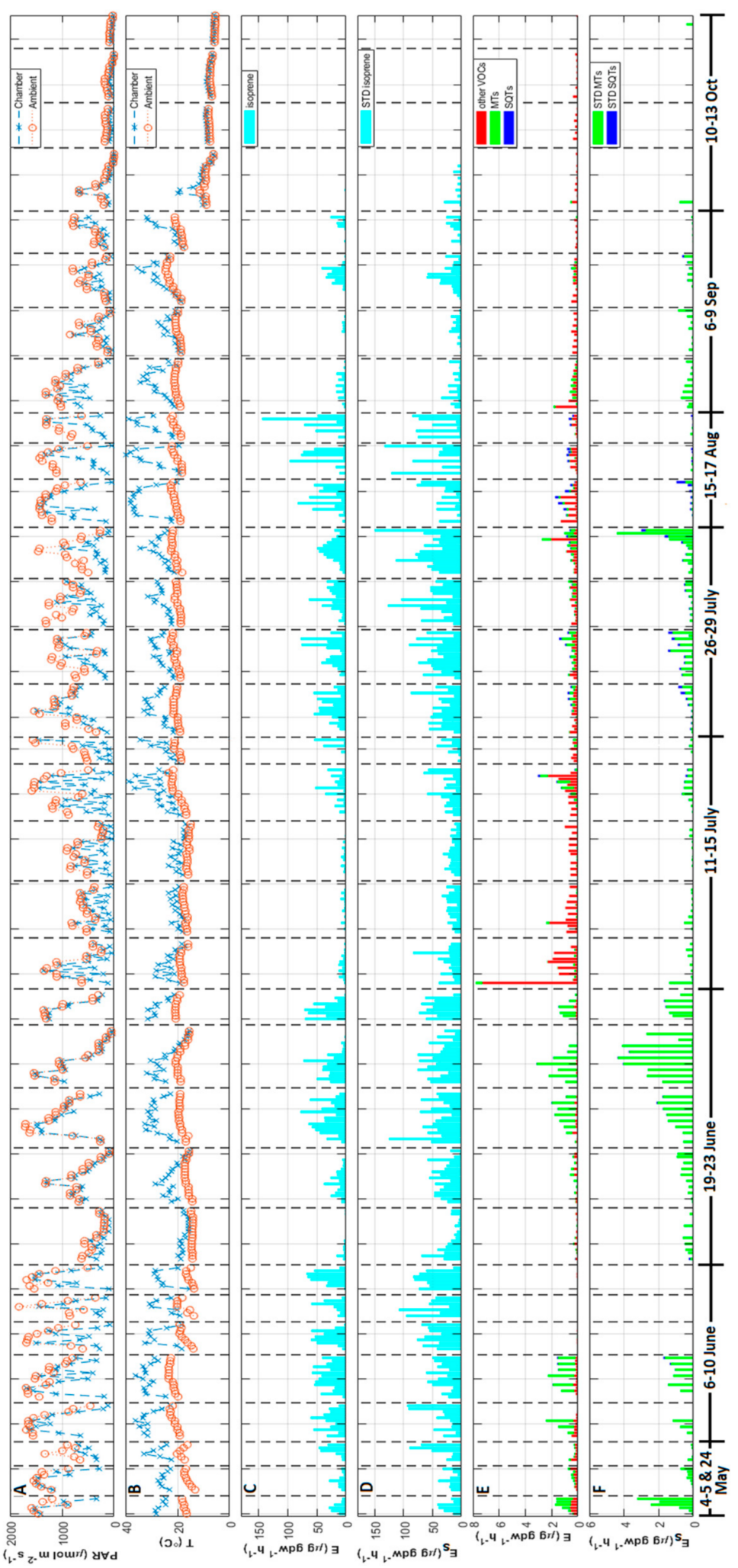

Figure 2. Measurements with branch chambers in 2016. (A) PAR $\left(\mu \mathrm{mol} \mathrm{m} \mathrm{m}^{-2} \mathrm{~s}^{-1}\right)$ values for chamber condition ( $\mathrm{PAR}_{\mathrm{C}}$, blue cross and dashed line) and ambient condition (red circle and dotted line). (B) Temperature $\left({ }^{\circ} \mathrm{C}\right)$ values for chamber condition ( $\mathrm{T}_{\mathrm{C}}$, blue cross and dashed line) and ambient condition (red circle and dotted line). (C) Emission rates $\left(\mu \mathrm{g} \mathrm{g}_{\mathrm{dw}}{ }^{-1} \mathrm{~h}^{-1}\right)$ for isoprene (cyan). (D) Standardized (STD) emission rates $\left(\mu \mathrm{g} \mathrm{g}_{\mathrm{dw}}{ }^{-1} \mathrm{~h}^{-1}\right.$ ) for isoprene (cyan). (E) Emission rates $\left(\mu \mathrm{g} \mathrm{g} \mathrm{dw}^{-1} \mathrm{~h}^{-1}\right.$ ) of other VOCs (red), monoterpenes (MTs, green), and sesquiterpenes (SQTs, blue). (F) STD emission rates $\left(\mu \mathrm{g} \mathrm{g}_{\mathrm{dw}}{ }^{-1} \mathrm{~h}^{-1}\right.$ ) for MTs (green) and SQTs (blue). Vertical dashed lines separate the different days. Each bar represents individual measurements. 
A

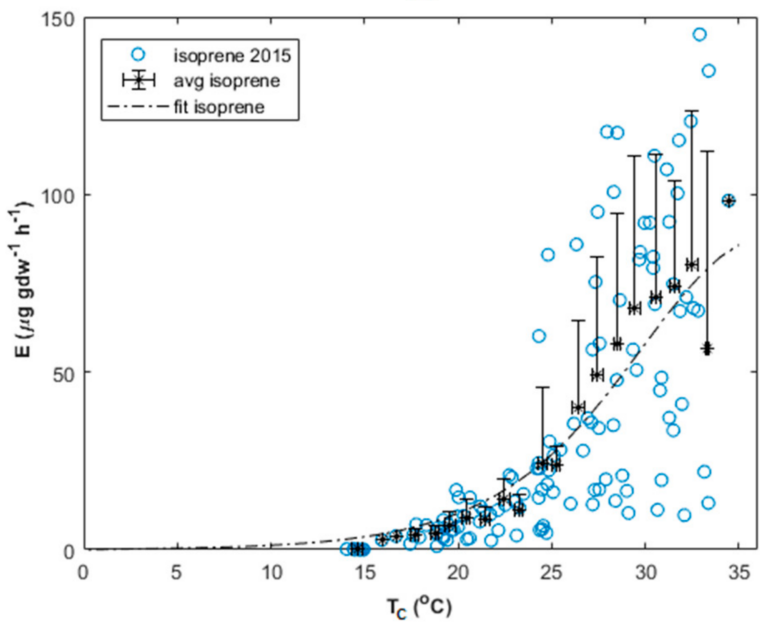

B

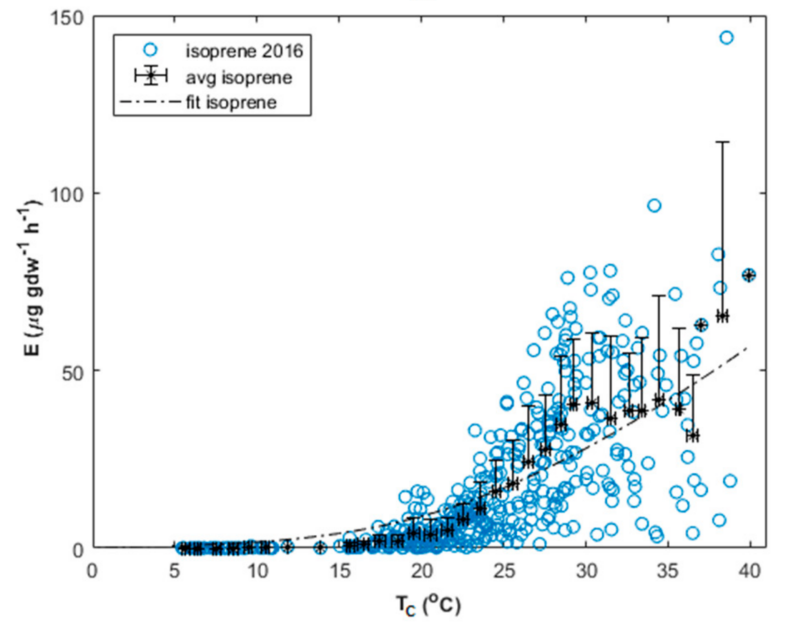

Figure 3. Measured isoprene emissions (blue circles, $\mu \mathrm{g} \mathrm{g}_{\mathrm{dw}}{ }^{-1} \mathrm{~h}^{-1}$ ), calculated mean emissions + SD (black stars, $\mu \mathrm{g} \mathrm{g} \mathrm{dw}^{-1} \mathrm{~h}^{-1}$ ), and fitted isoprene emission curves according to Equation (2) versus chamber temperature $\left(\mathrm{T}_{\mathrm{C}},{ }^{\circ} \mathrm{C}\right)$ from (A) P1 in 2015 and (B) P2 in 2016. Values for the parameters can be found in Table S4.

\subsubsection{Monoterpenes}

The emitted MTs from P1 in 2015 were $\alpha$-pinene, eucalyptol, linalool, and ocimene. The average STD MT emission was $0.365( \pm 0.151) \mu \mathrm{g} \mathrm{g}_{\mathrm{dw}}{ }^{-1} \mathrm{~h}^{-1}$. Ocimene was emitted during all campaigns and the highest measured emissions were seen during the first campaign in mid-July $\left(0.409-1.648 \mu \mathrm{g} \mathrm{g}_{\mathrm{dw}}{ }^{-1} \mathrm{~h}^{-1}\right)$ and the fourth campaign in mid-August $\left(0-0.932 \mu \mathrm{g} \mathrm{g}_{\mathrm{dw}}{ }^{-1} \mathrm{~h}^{-1}\right)$. Ocimene contributed with ca $93-100 \%$ to the average STD MT emission rate during all campaigns in 2015 (Table S3), and STD emissions of ocimene peaked $\left(1.631 \mu \mathrm{g} \mathrm{g}_{\mathrm{dw}}{ }^{-1} \mathrm{~h}^{-1}\right)$ in July. $\alpha$-pinene was the second most abundant MT in 2015 , with the STD emission ranging from 0 to $0.076 \mu \mathrm{g} \mathrm{g}_{\mathrm{dw}}{ }^{-1} \mathrm{~h}^{-1}$, but $\alpha$-pinene was not observed in September 2015. The total average STD MT emission decreased from $0.580( \pm 0.292) \mu \mathrm{g} \mathrm{g}_{\mathrm{dw}}{ }^{-1} \mathrm{~h}^{-1}$ in July to $0.286( \pm 0.182) \mu \mathrm{g} \mathrm{g} \mathrm{dw}^{-1} \mathrm{~h}^{-1}$ in September and a similar trend was seen for the measured average total MT emission.

More MTs were emitted from P2 in 2016. Except for the MTs mentioned above, alloocimene, limonene, myrcene, p-cymene, and 3-carene were also observed. The average STD emission of MTs was $0.281( \pm 0.222) \mu \mathrm{g} \mathrm{g}_{\mathrm{dw}}{ }^{-1} \mathrm{~h}^{-1}$. Like in 2015, ocimene dominated over the other MTs in 2016 but with higher measured $\left(0-2.930 \mu \mathrm{g} \mathrm{g}_{\mathrm{dw}}{ }^{-1} \mathrm{~h}^{-1}\right)$ and STD emission rates $\left(0-4.277 \mu \mathrm{g} \mathrm{g}_{\mathrm{dw}}{ }^{-1} \mathrm{~h}^{-1}\right)$. The measured emission peaked in June and the STD emission peaked in July. Instead of $\alpha$-pinene, linalool was the second most abundant MT in 2016. The highest measured $\left(0-0.206 \mu \mathrm{g} \mathrm{g}_{\mathrm{dw}}{ }^{-1} \mathrm{~h}^{-1}\right)$ and STD $\left(0-0.335 \mu \mathrm{g} \mathrm{g} \mathrm{dw}^{-1} \mathrm{~h}^{-1}\right)$ emissions of linalool occurred in May, and together with ocimene they contributed with more than $97 \%$ to the STD MT emission in May. Throughout the rest of the season in 2016 and until September, they contributed with ca 95-99\% to the average STD MT emission. Myrcene and allo-ocimene were only seen in June. The STD MT emission during 2016 was highest in May $\left(0.590 \pm 0.306 \mu \mathrm{g} \mathrm{g}_{\mathrm{dw}}{ }^{-1} \mathrm{~h}^{-1}\right)$ followed by June $\left(0.488 \pm 0.330 \mu \mathrm{g} \mathrm{g}_{\mathrm{dw}}{ }^{-1} \mathrm{~h}^{-1}\right)$, and lowest in October $\left(0.022 \pm 0.028 \mu \mathrm{g} \mathrm{g}_{\mathrm{dw}}{ }^{-1} \mathrm{~h}^{-1}\right)$. This pattern was also observed for the measured average total MT emission, which is in line with the MT emission trend in 2015.

\subsubsection{Sesquiterpenes}

The average STD emission of SQTs from P1 in 2015 was $0.082( \pm 0.060) \mu \mathrm{g} \mathrm{g}_{\mathrm{dw}}{ }^{-1} \mathrm{~h}^{-1}$. Caryophyllene had the highest emission rate among the SQTs in 2015 and the STD emission varied between 0 and $0.478 \mu \mathrm{g} \mathrm{g}_{\mathrm{dw}}{ }^{-1} \mathrm{~h}^{-1}$. The highest STD emissions occurred in September and caryophyllene was the only emitted SQT this month (Figure 1E and Table S3). The measured SQT emission peaked in the second half of August. $\alpha$-farnesene had the second highest average emission rate among the SQTs during 2015 and was emitted in July 
and August. Measured emissions of $\alpha$-farnesene $\left(0-0.242 \mu \mathrm{g} \mathrm{g}_{\mathrm{dw}}{ }^{-1} \mathrm{~h}^{-1}\right)$ were highest in August but STD emissions $\left(0-0.193 \mu \mathrm{g} \mathrm{g}_{\mathrm{dw}}{ }^{-1} \mathrm{~h}^{-1}\right)$ peaked already in late July.

The average STD SQT emission from P2 in 2016 was $0.012( \pm 0.018) \mu \mathrm{g} \mathrm{g}_{\mathrm{dw}}{ }^{-1} \mathrm{~h}^{-1}$ and the same SQTs were observed this year as during 2015. August was the month where both the STD emission $\left(0.054 \pm 0.046 \mu \mathrm{g} \mathrm{g}_{\mathrm{dw}}{ }^{-1} \mathrm{~h}^{-1}\right)$ and the measured emission $\left(0.084 \pm 0.057 \mu \mathrm{g} \mathrm{g}_{\mathrm{dw}}{ }^{-1} \mathrm{~h}^{-1}\right)$ peaked during 2016. Caryophyllene dominated between June and August and the STD emission varied from 0 to $0.215 \mu \mathrm{g} \mathrm{g}_{\mathrm{dw}}{ }^{-1} \mathrm{~h}^{-1}$. It contributed with ca $64-96 \%$ to the STD SQT emission during these months. $\alpha$-farnesene was emitted from July to September with STD emissions between 0 and $0.345 \mu \mathrm{g} \mathrm{g}_{\mathrm{dw}}{ }^{-1} \mathrm{~h}^{-1}$. It was the only SQT observed in September. Humulene was seen from June to July, where the STD emission ranged from 0 to $0.043 \mu \mathrm{g} \mathrm{g}_{\mathrm{dw}}{ }^{-1} \mathrm{~h}^{-1}$. No SQTs were emitted in May and October.

\subsubsection{Other VOCs}

The average emission of other VOCs at P1 in 2015 was $0.937\left( \pm 0.105 \mu \mathrm{g} \mathrm{g}_{\mathrm{dw}}{ }^{-1} \mathrm{~h}^{-1}\right)$. The highest emissions occurred in the beginning of August and the average emission for this campaign was $2.766( \pm 0.186) \mu \mathrm{g} \mathrm{g}_{\mathrm{dw}}{ }^{-1} \mathrm{~h}^{-1}$, which was several times higher compared with most of the other campaigns in 2015 and 2016 (Figures $1 \mathrm{~F}$ and 2F). The compounds that contributed most in August were nonanal $\left(0-1.570 \mu \mathrm{g} \mathrm{g}_{\mathrm{dw}}{ }^{-1} \mathrm{~h}^{-1}\right)$, benzoic acid $\left(0-1.330 \mu \mathrm{g} \mathrm{g}_{\mathrm{dw}}{ }^{-1} \mathrm{~h}^{-1}\right)$, benzaldehyde $\left(0-0.896 \mu \mathrm{g} \mathrm{g}_{\mathrm{dw}}{ }^{-1} \mathrm{~h}^{-1}\right)$, decanal $\left(0-0.800 \mu \mathrm{g} \mathrm{g}_{\mathrm{dw}}{ }^{-1} \mathrm{~h}^{-1}\right)$, octanal $\left(0-0.634 \mu \mathrm{g} \mathrm{g}_{\mathrm{dw}}{ }^{-1} \mathrm{~h}^{-1}\right)$, and hexanal $\left(0-0.607 \mu \mathrm{g} \mathrm{g}_{\mathrm{dw}}{ }^{-1} \mathrm{~h}^{-1}\right)$. The emissions of many compounds increased during the August campaign compared with the rest in 2015. Compounds such as nonanal and hexanal increased 4-fold, while benzoic acid increased almost 17-fold. The lowest emissions during 2015 were observed in September.

The average emission of other VOCs in 2016 was $0.279\left( \pm 0.049 \mu \mathrm{g} \mathrm{g}_{\mathrm{dw}}{ }^{-1} \mathrm{~h}^{-1}\right)$. The majority of the highest other VOC emissions were observed during July and especially during mid-July. The emissions of nonanal and benzaldehyde varied from 0 to $1.060 \mu \mathrm{g} \mathrm{g} \mathrm{dw}^{-1} \mathrm{~h}^{-1}$ and 0 to $0.701 \mu \mathrm{g} \mathrm{g}_{\mathrm{dw}}{ }^{-1} \mathrm{~h}^{-1}$ in July, respectively, but during the other months they were usually less than $0.200 \mu \mathrm{g} \mathrm{g}_{\mathrm{dw}}{ }^{-1} \mathrm{~h}^{-1}$. Emissions of 2-ethylhexanol also peaked in July $\left(0.974 \mu \mathrm{g} \mathrm{g}_{\mathrm{dw}^{-1}} \mathrm{~h}^{-1}\right)$. Octanal peaked in July but higher emissions were seen in both May and July $\left(0-0.441 \mu \mathrm{g} \mathrm{g}_{\mathrm{dw}}{ }^{-1} \mathrm{~h}^{-1}\right)$ compared with the other months $\left(0-0.089 \mu \mathrm{g} \mathrm{g}_{\mathrm{dw}}{ }^{-1} \mathrm{~h}^{-1}\right)$. Tetradecane was only observed in July and August $\left(0-0.034 \mu \mathrm{g} \mathrm{g}_{\mathrm{dw}}{ }^{-1} \mathrm{~h}^{-1}\right)$, where it peaked in August, and pentadecane was seen in July, August, and September $\left(0-0.072 \mu \mathrm{g} \mathrm{g}_{\mathrm{dw}}{ }^{-1} \mathrm{~h}^{-1}\right)$.

\subsection{Height Comparison with Branch Chamber Measurements in 2016}

The average STD isoprene emission from the middle canopy height $\mathrm{z}_{\mathrm{M}}$ $\left(33.6 \pm 28.2 \mu \mathrm{g} \mathrm{g}_{\mathrm{dw}}{ }^{-1} \mathrm{~h}^{-1}\right)$ did not significantly differ from the upper canopy height $\mathrm{z}_{\mathrm{H}}\left(26.7 \pm 24.1 \mu \mathrm{g} \mathrm{g} \mathrm{dw}^{-1} \mathrm{~h}^{-1}\right)$. The largest difference between $\mathrm{z}_{\mathrm{M}}$ and $\mathrm{z}_{\mathrm{H}}$ for the STD isoprene emission was observed in August (Tables 4 and 5). Due to P. vulgatissima, leaves at $z_{H}$ were more damaged than at $z_{M}$ in August, which could be one explanation for the different STD isoprene emissions.

Comparing MT emissions between the heights showed that $z_{\mathrm{H}}$ emitted higher rates of MTs than $z_{M}$. The average STD MT emission from $z_{H}$ was $0.509( \pm 0.294) \mu g g_{d w}{ }^{-1}$ $\mathrm{h}^{-1}$ and ca 5 times higher compared with $\mathrm{z}_{\mathrm{M}}\left(0.102 \pm 0.137 \mu \mathrm{g} \mathrm{g} \mathrm{dw}^{-1} \mathrm{~h}^{-1} ; p<0.05\right)$. The only time when the average STD MT emission from $z_{M}$ exceeded that from $z_{H}$ was in May and October (Tables 4 and 5). In October, it was difficult to find any intact leaves at $\mathrm{z}_{\mathrm{H}}$ (Figure S3). Consequently, the leaves at $\mathrm{z}_{\mathrm{H}}$ were not able to emit any observable MTs in October. The number of emitted MT compounds from $\mathrm{z}_{\mathrm{H}}$ was also larger compared with $\mathrm{z}_{\mathrm{M}}$, which did not have emissions of myrcene and allo-ocimene. Ocimene was the dominantly emitted MT from both $\mathrm{z}_{\mathrm{M}}(0-91.9 \%)$ and $\mathrm{z}_{\mathrm{H}}(0-96.8 \%)$, and linalool also contributed substantially to the MT emission for $\mathrm{z}_{\mathrm{H}}(0-81.7 \%)$. Limonene $(0-50.0 \%)$, p-cymene $(0-33.3 \%)$ and 3-carene $(0-25.0 \%)$ only had a significant contribution for $z_{M}$. The only MTs that were observed in October ( $\alpha$-pinene, 3-carene, and limonene) were emitted from $\mathrm{z}_{\mathrm{M}}$. 
Table 4. Emission rates (STD for isoprene, MTs, and SQTs, $\mu \mathrm{g} \mathrm{g}_{\mathrm{dw}}{ }^{-1} \mathrm{~h}^{-1}$ ) and fraction (\%) of the total BVOC emission or within the BVOC group (MTs and SQTs) from $z_{H}$ in 2016. Bottom: average $T_{C}\left({ }^{\circ} \mathrm{C}\right), \operatorname{PAR}_{C}\left(\mu \mathrm{mol} \mathrm{m}^{-2} \mathrm{~s}^{-1}\right)$, and the corresponding SD for each month.

\begin{tabular}{|c|c|c|c|c|c|c|}
\hline $2016 z_{H}$ & May & June & July & Aug & Sep & Oct \\
\hline isoprene & $44.8(99.1 \%)$ & $32.6(95.8 \%)$ & $37.5(98.3 \%)$ & $11.1(97.8 \%)$ & $18.2(98.1 \%)$ & $0.2(87.3 \%)$ \\
\hline MTs (tot) & $0.127(0.3 \%)$ & $1.240(3.6 \%)$ & $0.371(1.0 \%)$ & $0.071(0.6 \%)$ & $0.275(1.5 \%)$ & 0 \\
\hline$\alpha$-pinene & 0 & $<0.001(<0.1 \%)$ & $0.001(0.3 \%)$ & $0.001(1.4 \%)$ & $0.001(0.4 \%)$ & 0 \\
\hline myrcene & 0 & $<0.001(<0.1 \%)$ & 0 & 0 & 0 & 0 \\
\hline 3 -carene & $0.008(6.3 \%)$ & 0 & $<0.001(0.1 \%)$ & $0.001(1.4 \%)$ & 0 & 0 \\
\hline ocimene & $0.004(3.2 \%)$ & $1.200(96.8 \%)$ & $0.358(96.4 \%)$ & $0.038(53.6 \%)$ & $0.257(93.4 \%)$ & 0 \\
\hline limonene & $0.004(3.2 \%)$ & $<0.001(<0.1 \%)$ & $0.003(0.8 \%)$ & 0 & 0 & 0 \\
\hline linalool & $0.104(81.7 \%)$ & $0.033(2.7 \%)$ & $0.007(1.9 \%)$ & $0.028(39.4 \%)$ & $0.016(5.8 \%)$ & 0 \\
\hline p-cymene & $0.003(2.4 \%)$ & $<0.001(<0.1 \%)$ & $<0.001(0.2 \%)$ & $0.001(1.4 \%)$ & 0 & 0 \\
\hline allo-ocimene & 0 & $<0.001(<0.1 \%)$ & 0 & 0 & 0 & 0 \\
\hline eucalyptol & $0.004(3.2 \%)$ & $0.004(0.3 \%)$ & $0.001(0.3 \%)$ & $0.002(2.8 \%)$ & $0.001(0.4 \%)$ & 0 \\
\hline SQTs (tot) & 0 & $0.010(<0.1 \%)$ & $0.043(0.1 \%)$ & 0 & $0.007(<0.1 \%)$ & 0 \\
\hline$\alpha$-farnesene & 0 & 0 & $0.002(4.7 \%)$ & 0 & $0.007(100 \%)$ & 0 \\
\hline humulene & 0 & $<0.001(10.0 \%)$ & $0.005(11.6 \%)$ & 0 & 0 & 0 \\
\hline caryophyllene & 0 & $0.009(90.0 \%)$ & $0.036(83.7 \%)$ & 0 & 0 & 0 \\
\hline other VOCs (tot) & $0.262(0.6 \%)$ & $0.172(0.5 \%)$ & $0.228(0.6 \%)$ & $0.176(1.6 \%)$ & $0.067(0.4 \%)$ & $0.029(12.7 \%)$ \\
\hline BVOCs (tot) & $45.189(100 \%)$ & $34.021(100 \%)$ & $38.140(100 \%)$ & $11.347(100 \%)$ & $18.549(100 \%)$ & $0.229(100 \%)$ \\
\hline $\mathrm{T}_{\mathrm{C}}$ & $26.9(3.5)$ & $24.5(6.0)$ & $25.5(4.8)$ & $31.1(6.4)$ & $25.7(4.4)$ & $8.8(2.9)$ \\
\hline $\mathrm{PAR}_{\mathrm{C}}$ & $521(149)$ & $727(494)$ & $629(365)$ & $833(445)$ & $313(235)$ & $96(126)$ \\
\hline
\end{tabular}

Table 5. Emission rates (STD for isoprene, MTs, and SQTs, $\mu \mathrm{g} \mathrm{g}_{\mathrm{dw}}{ }^{-1} \mathrm{~h}^{-1}$ ) and fraction (\%) of the total BVOC emission or within the BVOC group (MTs and SQTs) from $z_{M}$ in 2016. Bottom: average $T_{C}\left({ }^{\circ} C\right), P_{C}\left(\mu R_{C}\left(m^{-2} s^{-1}\right)\right.$, and the corresponding SD for each month.

\begin{tabular}{|c|c|c|c|c|c|c|}
\hline $2016 z_{M}$ & May & June & July & Aug & Sep & Oct \\
\hline isoprene & $23.5(95.3 \%)$ & $48.7(99.8 \%)$ & $34.0(97.4 \%)$ & $60.5(98.9 \%)$ & $9.6(96.0 \%)$ & $2.8(93.6 \%)$ \\
\hline MTs (tot) & $0.788(3.2 \%)$ & $0.005(<0.1 \%)$ & $0.147(0.4 \%)$ & $0.062(0.1 \%)$ & $0.012(0.1 \%)$ & $0.042(1.4 \%)$ \\
\hline$\alpha$-pinene & 0 & $<0.001(15.9 \%)$ & $0.004(2.7 \%)$ & 0 & 0 & $0.007(16.7 \%)$ \\
\hline myrcene & 0 & 0 & 0 & 0 & 0 & 0 \\
\hline 3-carene & $0.002(0.3 \%)$ & $<0.001(6.2 \%)$ & $0.005(3.4 \%)$ & 0 & $0.003(25.0 \%)$ & $0.014(33.3 \%)$ \\
\hline ocimene & $0.701(89.0 \%)$ & $0.003(55.9 \%)$ & $0.121(82.3 \%)$ & $0.057(91.9 \%)$ & 0 & 0 \\
\hline limonene & 0 & 0 & $0.001(0.7 \%)$ & 0 & $0.003(25.0 \%)$ & $0.021(50.0 \%)$ \\
\hline linalool & $0.071(9.0 \%)$ & 0 & $<0.001(<0.1 \%)$ & $0.005(8.1 \%)$ & 0 & 0 \\
\hline p-cymene & $0.001(0.1 \%)$ & $0.001(22.0 \%)$ & $0.006(4.1 \%)$ & 0 & $0.004(33.3 \%)$ & 0 \\
\hline allo-ocimene & 0 & 0 & 0 & 0 & 0 & 0 \\
\hline eucalyptol & $0.013(1.6 \%)$ & 0 & $0.010(6.8 \%)$ & 0 & $0.002(16.7 \%)$ & 0 \\
\hline SQTs (tot) & 0 & 0 & 0 & $0.086(0.1 \%)$ & 0 & 0 \\
\hline$\alpha$-farnesene & 0 & 0 & 0 & $0.021(24.4 \%)$ & 0 & 0 \\
\hline humulene & 0 & 0 & 0 & $0.009(10.5 \%)$ & 0 & 0 \\
\hline caryophyllene & 0 & 0 & 0 & $0.056(65.1 \%)$ & 0 & 0 \\
\hline other VOCs (tot) & $0.359(1.5 \%)$ & $0.077(0.2 \%)$ & $0.761(2.2 \%)$ & $0.531(0.9 \%)$ & $0.386(3.9 \%)$ & $0.149(5.0 \%)$ \\
\hline BVOCs (tot) & $24.647(100 \%)$ & $48.782(100 \%)$ & $34.908(100 \%)$ & $61.179(100 \%)$ & $9.998(100 \%)$ & $2.991(100 \%)$ \\
\hline $\mathrm{T}_{\mathrm{C}}$ & $25.7(1.7)$ & $25.4(5.6)$ & $23.1(3.9)$ & $31.1(7.0)$ & $24.3(4.7)$ & $8.6(2.5)$ \\
\hline $\mathrm{PAR}_{\mathrm{C}}$ & $1135(406)$ & $699(469)$ & $298(254)$ & $627(450)$ & $486(342)$ & 83 (123) \\
\hline
\end{tabular}

The STD SQT emission from $\mathrm{z}_{\mathrm{H}}\left(0.019 \pm 0.023 \mu \mathrm{g} \mathrm{g}_{\mathrm{dw}}{ }^{-1} \mathrm{~h}^{-1}\right)$ was almost three times larger than from $\mathrm{z}_{\mathrm{M}}\left(0.007 \pm 0.018 \mu \mathrm{g} \mathrm{g}_{\mathrm{dw}}{ }^{-1} \mathrm{~h}^{-1} ; p<0.05\right)$. The same SQTs were observed at 
both heights ( $\alpha$-farnesene, caryophellene, and humulene). Sesquiterpenes were seen from $\mathrm{z}_{\mathrm{H}}$ in June, July, and September, but only in August from $\mathrm{z}_{\mathrm{M}}$ (Tables 4 and 5). Caryophyllene was the dominantly emitted SQT for $\mathrm{z}_{\mathrm{H}}(0-90.0 \%)$ and $\mathrm{z}_{\mathrm{M}}(0-65.0 \%)$.

The number of other VOCs from $z_{H}(20)$ was almost the same as from $z_{M}(22)$ but the average emission from $\mathrm{z}_{\mathrm{M}}\left(0.347 \pm 0.061 \mu \mathrm{g} \mathrm{g} \mathrm{dw}^{-1} \mathrm{~h}^{-1}\right)$ was more than twice as high compared with $\mathrm{z}_{\mathrm{H}}\left(0.159 \pm 0.030 \mu \mathrm{g} \mathrm{g}_{\mathrm{dw}}{ }^{-1} \mathrm{~h}^{-1} ; p<0.05\right)$. The highest average emission of other VOCs from $\mathrm{z}_{\mathrm{M}}$ occurred during July. The compounds that contributed most to this emission in July were benzaldehyde, cyclopentenyl acetylene, 2-ethylhexanol, nonanal, hexanal, and octanal. The average other VOC emission from $z_{\mathrm{H}}$ was highest in May followed by July. Nonanal, hexanal, octanal, and acetophenone were the dominant other VOCs from $z_{H}$ during May. The average emission of 2-ethylhexanol was 16 times higher from $z_{M}$ compared with $z_{H}$. Hexanal, benzaldehyde, and octanal were 3-4 times higher from $z_{M}$ compared with $z_{H}$. The other VOC emission from $z_{H}$ was considerably lower at the end of the growing season whereas $\mathrm{z}_{\mathrm{M}}$ still emitted higher amounts during September and October.

\subsection{Light Response Curves with Leaf Chamber}

Starting in the middle of July 2016 and ending in September, light response curves were measured with a leaf chamber at different heights (Table 2). The average emission of isoprene from $\mathrm{z}_{\mathrm{H}}$ was $42.2( \pm 31.6) \mu \mathrm{g} \mathrm{g} \mathrm{dw}^{-1} \mathrm{~h}^{-1}$ (or $2.42 \pm 1.69 \mathrm{mgC} \mathrm{m}^{-2} \mathrm{~h}^{-1}$ ) and almost twice as high as $\mathrm{z}_{\mathrm{L}}\left(22.1 \pm 17.3 \mu \mathrm{g} \mathrm{g}_{\mathrm{dw}^{-1}} \mathrm{~h}^{-1}\right.$ or $\left.1.22 \pm 0.84 \mathrm{mgC} \mathrm{m}^{-2} \mathrm{~h}^{-1}\right)$. The isoprene emission from $\mathrm{z}_{\mathrm{M}}\left(33.6 \pm 30.9 \mu \mathrm{g} \mathrm{g}_{\mathrm{dw}}{ }^{-1} \mathrm{~h}^{-1}\right.$ or $\left.1.58 \pm 1.54 \mathrm{mgC} \mathrm{m}^{-2} \mathrm{~h}^{-1}\right)$ was in between $\mathrm{z}_{\mathrm{H}}$ and $\mathrm{z}_{\mathrm{L}}$ but the average $\mathrm{T}_{\mathrm{C}}$ and PAR $\mathrm{P}_{\mathrm{C}}$ for $\mathrm{z}_{\mathrm{M}}\left(22.7 \pm 2.4^{\circ} \mathrm{C}\right.$ and $497 \pm 451 \mu \mathrm{mol} \mathrm{m}{ }^{-2} \mathrm{~s}^{-1}$, respectively) were lower than for $\mathrm{z}_{\mathrm{H}}\left(24.9 \pm 0.1{ }^{\circ} \mathrm{C}\right.$ and $571 \pm 484 \mu \mathrm{mol} \mathrm{m}{ }^{-2} \mathrm{~s}^{-1}$, respectively) and $\mathrm{z}_{\mathrm{L}}\left(24.8 \pm 0.1{ }^{\circ} \mathrm{C}\right.$ and $571 \pm 484 \mu \mathrm{mol} \mathrm{m}{ }^{-2} \mathrm{~s}^{-1}$, respectively). The corresponding STD emissions for these height levels were $96.1( \pm 64.6) \mathrm{\mu g} \mathrm{g}_{\mathrm{dw}}{ }^{-1} \mathrm{~h}^{-1}$ (or


$\left(\mathrm{z}_{\mathrm{M}}\right)$, and $51.8( \pm 32.9) \mu \mathrm{g} \mathrm{g}_{\mathrm{dw}}{ }^{-1} \mathrm{~h}^{-1}\left(2.88 \pm 1.57 \mathrm{mgC} \mathrm{m}^{-2} \mathrm{~h}^{-1}\right)\left(\mathrm{z}_{\mathrm{L}}\right)$. Both the measured and the STD isoprene emission for $z_{\mathrm{H}}$ and $\mathrm{z}_{\mathrm{L}}$ were significantly different.

In particular, the response to PAR differed between the height levels under lowlight conditions for measured isoprene emissions (Figure 4A). For instance, the slope between 0 and $150 \mu \mathrm{mol} \mathrm{m}{ }^{-2} \mathrm{~s}^{-1}$ for $\mathrm{z}_{\mathrm{H}}$ was $0.140 \mu \mathrm{g} \mathrm{g} \mathrm{dw}^{-1} \mathrm{~h}^{-1} /\left(\mu \mathrm{mol} \mathrm{m}^{-2} \mathrm{~s}^{-1}\right)$, while it was $0.058 \mu \mathrm{g} \mathrm{g}_{\mathrm{dw}}{ }^{-1} \mathrm{~h}^{-1} /\left(\mu \mathrm{mol} \mathrm{m}{ }^{-2} \mathrm{~s}^{-1}\right)$ for $\mathrm{z}_{\mathrm{L}}$ (Table S5). This fast response resulted in isoprene comprising more than $90 \%$ of the total BVOC emission already at $150 \mu \mathrm{mol} \mathrm{m}^{-2}$ $\mathrm{s}^{-1}$ for $\mathrm{z}_{\mathrm{H}}$ (Figure $5 \mathrm{~B}$ ). When comparing the STD isoprene emissions between $\mathrm{z}_{\mathrm{L}}$ and $\mathrm{z}_{\mathrm{H}}$, then the slope of the fitted curves differed less for low PAR values (Figure S4 and Table S6).

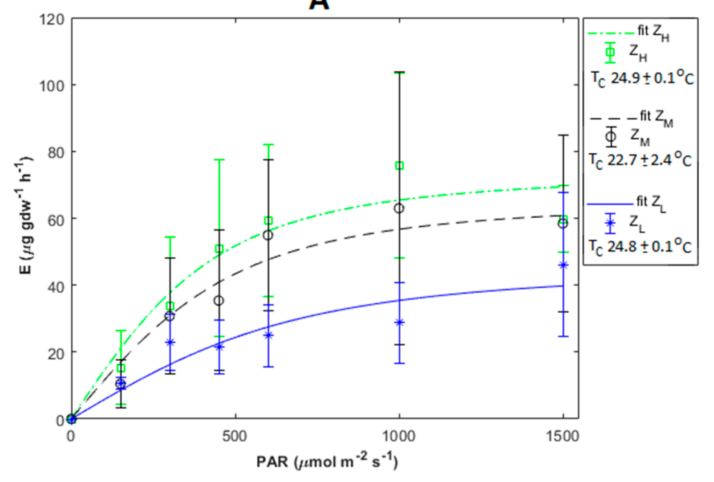

B

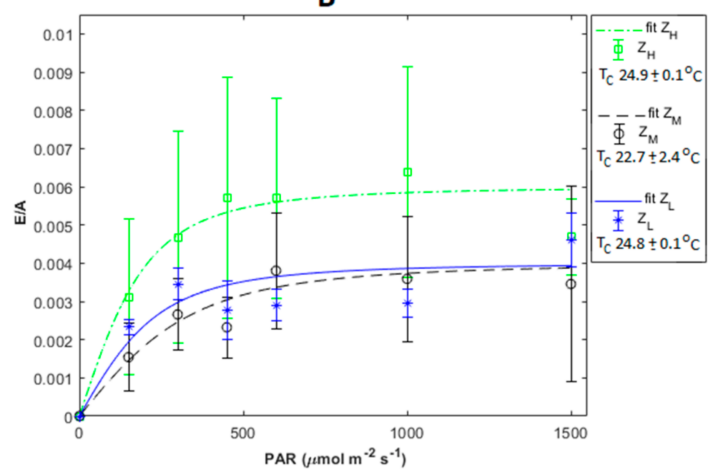

Figure 4. (A) Isoprene emission rates ( $\mu \mathrm{g} \mathrm{g} \mathrm{gdw}^{-1} \mathrm{~h}^{-1}$, mean $\left.\pm \mathrm{SD}, n=3-6\right)$ and fitted curves for different PAR values ( $\mu \mathrm{mol} \mathrm{m}{ }^{-2} \mathrm{~s}^{-1}$ ) at different heights using Equation (2). The chamber temperature ( $\mathrm{T}_{\mathrm{C}}$, mean $\left.\pm \mathrm{SD}, n=3-6\right)$ for each height level is included in the legend. Parameter values can be seen in Table S5. (B) Ratio between average isoprene emission and net assimilation (unitless, $n=3-6$ ) for different PAR values at different heights. The chamber temperature $\left(\mathrm{T}_{\mathrm{C}}\right.$, mean $\pm \mathrm{SD}$, $n=3-6$ ) for each height level is included in the legend. The fitted curves are based on Equation (S2) (see Supplementary Materials) and the parameter values can be found in Table S7. 
A

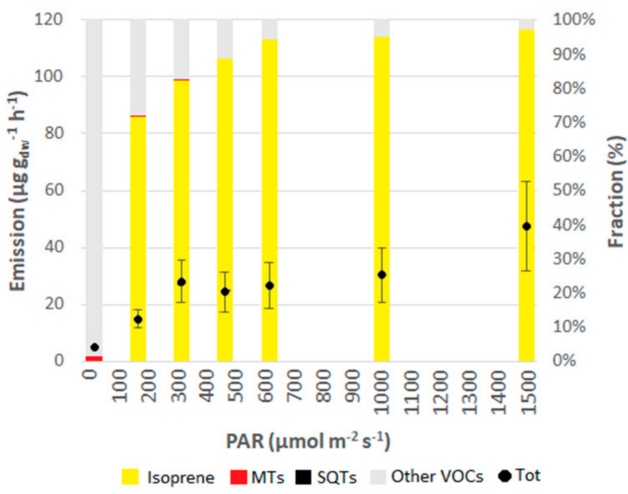

B

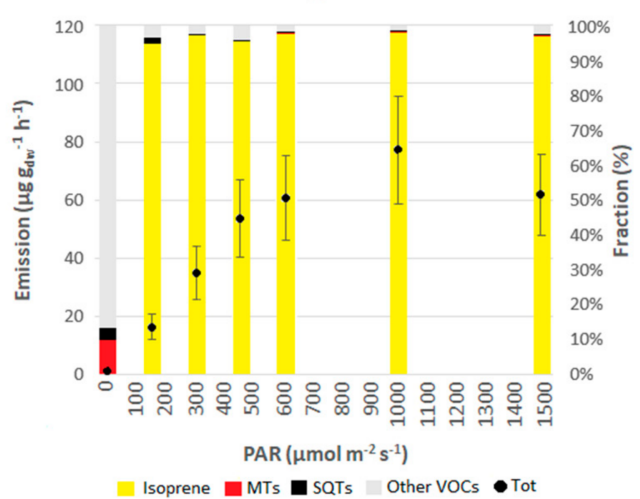

Figure 5. Total emission rates ( $\mu \mathrm{g} \mathrm{g}_{\mathrm{dw}}{ }^{-1} \mathrm{~h}^{-1}$, mean $\pm \mathrm{SD}$, black circles and left $y$-axis), and the percentages (stacked bars and right $y$-axis) for the different BVOC groups at different light levels $\left(\mu \mathrm{mol} \mathrm{m}{ }^{-2} \mathrm{~s}^{-1}\right)$. (A) Lower height $\left(\mathrm{z}_{\mathrm{L}}, n=3\right)$. (B) Higher height $\left(\mathrm{z}_{\mathrm{H}}, n=5\right)$.

The ratio between isoprene emission and net assimilation (E/A, dimensionless) showed that $\mathrm{z}_{\mathrm{H}}$ emitted more of the synthesized $\mathrm{C}$ as isoprene relative to the assimilated C, compared with $z_{M}$ and $z_{L}$ (Figure $4 B$ ). In particular, $z_{H}$ had the highest E/A ratio when PAR was $1000 \mu \mathrm{mol} \mathrm{m} \mathrm{m}^{-2} \mathrm{~s}^{-1}$ and more than $0.6 \%$ of the $C$ was emitted as isoprene. For $\mathrm{z}_{\mathrm{M}}$ and $\mathrm{z}_{\mathrm{L}}$, this value was less than $0.4 \%$ and $0.3 \%$, respectively. $\mathrm{z}_{\mathrm{L}}$ was the only height level that increased the E/A ratio from $1000 \mu \mathrm{mol} \mathrm{m}^{-2} \mathrm{~s}^{-1}$ (ca $0.30 \%$ ) to $1500 \mu \mathrm{mol} \mathrm{m}{ }^{-2} \mathrm{~s}^{-1}$ (ca $0.46 \%$ ).

One MT was seen at $z_{L}$ (limonene), four at $z_{H}(\alpha$-pinene, limonene, $p$-cymene, and ocimene), and five at $\mathrm{z}_{\mathrm{M}}$ (3-carene, $\alpha$-pinene, limonene, $\mathrm{p}$-cymene, and ocimene). Only ocimene seemed to be influenced by PAR and the average emission of ocimene increased when PAR varied from 300 to $1000 \mu \mathrm{mol} \mathrm{m} \mathrm{m}^{-2} \mathrm{~s}^{-1}$ (Figure 6A). The MT emission from $\mathrm{z}_{\mathrm{H}}$ $\left(0.078 \pm 0.085 \mu \mathrm{g} \mathrm{g}_{\mathrm{dw}}{ }^{-1} \mathrm{~h}^{-1}\right.$ or $\left.0.004 \pm 0.005 \mathrm{mgC} \mathrm{m}^{-2} \mathrm{~h}^{-1}\right)$ was almost twice as high as $\mathrm{z}_{\mathrm{L}}\left(0.045 \pm 0.029 \mu \mathrm{g} \mathrm{g}_{\mathrm{dw}}{ }^{-1} \mathrm{~h}^{-1}\right.$ or $\left.0.002 \pm 0.002 \mathrm{mgC} \mathrm{m}^{-2} \mathrm{~h}^{-1}\right)$. The MT fraction was in general lower than $1.0 \%$ for all heights and light levels, except when there was no light, due to no isoprene emission (Figures 5A,B and S5).

A

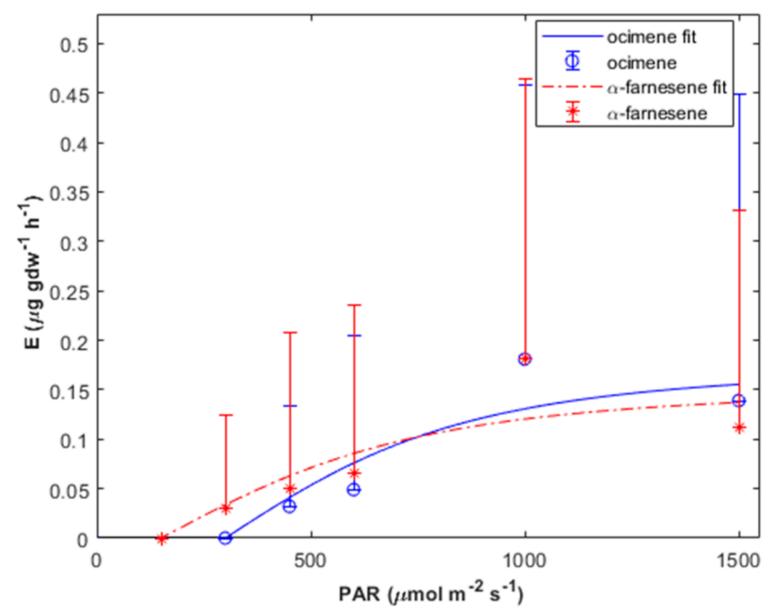

B

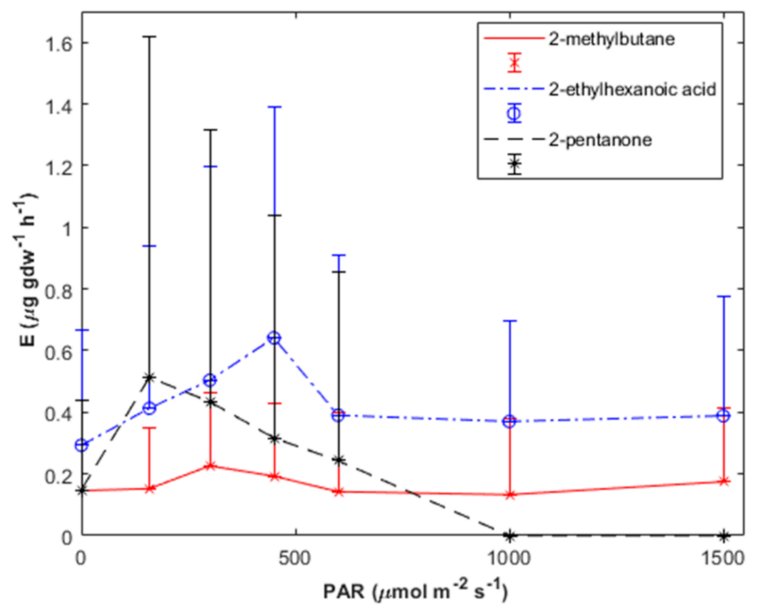

Figure 6. (A) Emissions ( $\mu \mathrm{g} \mathrm{g}_{\mathrm{dw}}{ }^{-1} \mathrm{~h}^{-1}$, mean $+\mathrm{SD}, n=11$ ) for ocimene (blue circles) and $\alpha$-farnesene (red stars) from height levels $\mathrm{z}_{\mathrm{M}}$ and $\mathrm{z}_{\mathrm{H}}$ at different light levels. Fitted curves have been done by a modified Equation (2), where $\mathrm{C}_{\mathrm{L}}$ has been replaced with Equation (S3) for ocimene and Equation (S4) for $\alpha$-farnesene (see Supplementary Materials for Equations (S3) and (S4) and Table S8 for values). (B) Emissions ( $\mu \mathrm{g} \mathrm{g}_{\mathrm{dw}}{ }^{-1} \mathrm{~h}^{-1}$, mean $+\mathrm{SD}, n=7-14$ ) for 2-methylbutane, (red cross), 2-ethylhexanoic acid, (blue circles), and 2-pentanone (black stars) from height levels $\mathrm{z}_{\mathrm{L}}$ and $\mathrm{z}_{\mathrm{M}}$. 
No SQTs were emitted from $z_{L}$. Three SQTs were observed at $z_{H}$ ( $\alpha$-farnesene, humulene, and nerolidol) and four at $\mathrm{z}_{\mathrm{M}}$ ( $\alpha$-farnesene, caryophyllene, humulene, and nerolidol). Average emissions of $\alpha$-farnesene increased when PAR varied from 150 to $1000 \mu \mathrm{mol} \mathrm{m}^{-2} \mathrm{~s}^{-1}$ (Figure 6A).

None of the observed other VOCs from the leaf chamber measurements showed a clear relationship with light. However, the emissions of a few compounds seemed to increase or decrease for certain PAR values. The average emission of 2-methylbutane increased from $0.145( \pm 0.148) \mu \mathrm{g} \mathrm{g}_{\mathrm{dw}}{ }^{-1} \mathrm{~h}^{-1}$ to $0.226( \pm 0.239) \mu \mathrm{g} \mathrm{g} \mathrm{dw}^{-1} \mathrm{~h}^{-1}$ when PAR varied between 0 and $300 \mu \mathrm{mol} \mathrm{m}{ }^{-2} \mathrm{~s}^{-1}$ and decreased thereafter (Figure $6 \mathrm{~B}$ ). The average emission of 2-ethylhexanoic acid ranged between 0.293 and $0.641 \mathrm{\mu g} \mathrm{g}_{\mathrm{dw}}{ }^{-1} \mathrm{~h}^{-1}$ for the PAR values $0-450 \mu \mathrm{mol} \mathrm{m}^{-2} \mathrm{~s}^{-1}$, but the opposite trend was seen for 2-pentanone, the average emission of which decreased from 0.330 to $0 \mu \mathrm{g} \mathrm{g}_{\mathrm{dw}}{ }^{-1} \mathrm{~h}^{-1}$ when PAR increased from 150 to $1000 \mu \mathrm{mol} \mathrm{m}{ }^{-2} \mathrm{~s}^{-1}$.

The average net assimilation at the maximum light intensity $\left(1500 \mu \mathrm{mol} \mathrm{m}^{-2} \mathrm{~s}^{-1}\right)$ at $\mathrm{z}_{\mathrm{M}}\left(21.30 \pm 2.92 \mu \mathrm{mol} \mathrm{CO} \mathrm{m}^{-2} \mathrm{~s}^{-1}\right)$ and $\mathrm{z}_{\mathrm{H}}\left(18.10 \pm 4.89 \mu \mathrm{mol} \mathrm{CO}_{2} \mathrm{~m}^{-2} \mathrm{~s}^{-1}\right)$ was higher than at $\mathrm{z}_{\mathrm{L}}\left(12.05 \pm 3.01 \mu \mathrm{mol} \mathrm{CO} \mathrm{m}^{-2} \mathrm{~s}^{-1}\right)$ (Figure 7A and Table 6). The average A values for each light step for $z_{M}$ and $z_{H}$ increased all the way up to $1500 \mu \mathrm{mol} \mathrm{m}^{-2} \mathrm{~s}^{-1}$, while the average $A$ for $\mathrm{z}_{\mathrm{L}}$ leveled out when PAR exceeded $600 \mu \mathrm{mol} \mathrm{m}^{-2} \mathrm{~s}^{-1}$. (Figure 7A and Table S9).
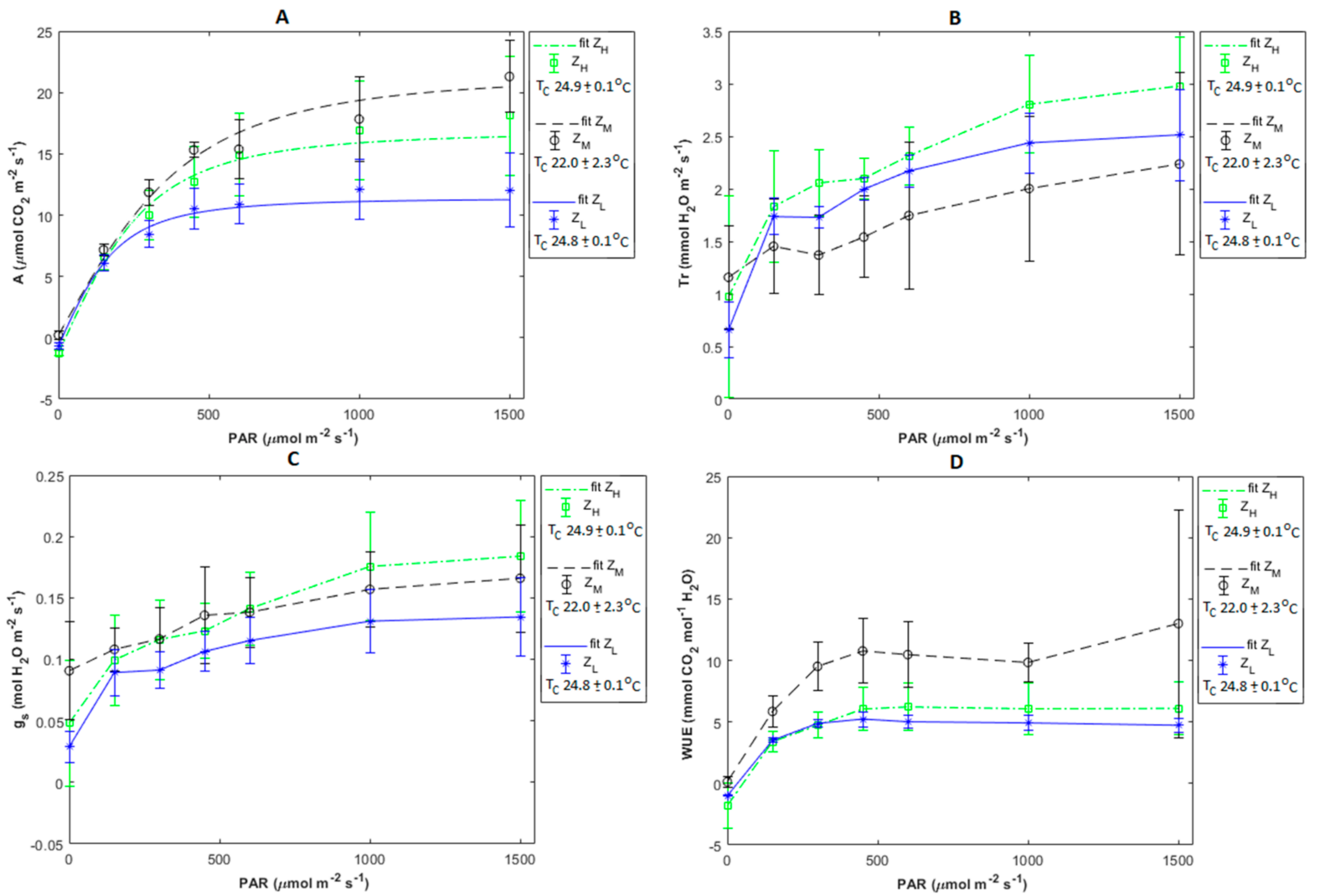

Figure 7. (A) Net assimilation (A, mean $\pm \mathrm{SD}, \mu \mathrm{mol} \mathrm{CO} \mathrm{CO}^{-2} \mathrm{~s}^{-1}, n=2-6$ ) and fitted curves by using Equation (6) (values of parameters can be seen in Table S10), (B) transpiration ( $\mathrm{Tr}$, mean $\left.\pm \mathrm{SD}, \mathrm{mmol} \mathrm{H}_{2} \mathrm{O} \mathrm{m}^{-2} \mathrm{~s}^{-1}, n=2-6\right),(\mathbf{C})$ stomatal conductance ( $\mathrm{g}_{\mathrm{s}}$, mean $\pm \mathrm{SD}$, $\mathrm{mol} \mathrm{H}_{2} \mathrm{O} \mathrm{m}^{-2} \mathrm{~s}^{-1}, n=2-6$ ), and (D) water use efficiency (WUE, mean $\pm \mathrm{SD}, \mathrm{mmol} \mathrm{CO}_{2} \mathrm{~mol}^{-1}$ $\left.\mathrm{H}_{2} \mathrm{O}, n=2-6\right)$ for different PAR $\left(\mu \mathrm{mol} \mathrm{m}{ }^{-2} \mathrm{~s}^{-1}\right)$ and height levels. The chamber temperature $\left(\mathrm{T}_{\mathrm{C}}, \mathrm{mean} \pm \mathrm{SD}, n=3-6\right)$ for each height level is included in all legends.

Transpiration at $\mathrm{z}_{\mathrm{H}}$ was higher than at $\mathrm{z}_{\mathrm{M}}$ and $\mathrm{z}_{\mathrm{L}}$ when there was light (Figure $7 \mathrm{~B}$ ). Stomatal conductance at $\mathrm{z}_{\mathrm{H}}$ exceeded $\mathrm{g}_{\mathrm{s}}$ at $\mathrm{z}_{\mathrm{M}}$ and $\mathrm{z}_{\mathrm{L}}$ at light intensities above $600 \mu \mathrm{mol} \mathrm{m}{ }^{-2} \mathrm{~s}^{-1}$ (Figure 7C). The lower height had the lowest $\mathrm{g}_{\mathrm{s}}$ response to PAR but was mainly in between $\mathrm{z}_{\mathrm{H}}$ and $\mathrm{z}_{\mathrm{M}}$ for Tr. Water use efficiency was similar for $\mathrm{z}_{\mathrm{H}}$ and $\mathrm{z}_{\mathrm{L}}$ when PAR varied between 
0 and $450 \mu \mathrm{mol} \mathrm{m}{ }^{-2} \mathrm{~s}^{-1}$; thereafter, $\mathrm{Z}_{\mathrm{H}}$ increased to ca $6 \mathrm{mmol} \mathrm{CO}_{2} \mathrm{~mol}^{-1} \mathrm{H}_{2} \mathrm{O}$ while $\mathrm{z}_{\mathrm{L}}$ was more or less constant and remained below $5 \mathrm{mmol} \mathrm{CO}_{2} \mathrm{~mol}^{-1} \mathrm{H}_{2} \mathrm{O}$ (Figure 7D). On the other hand, WUE for $z_{M}$ was approximately twice as high as for $z_{H}$ and $z_{L}$ for 450-1500 $\mu \mathrm{mol} \mathrm{m} \mathrm{m}^{-2} \mathrm{~s}^{-1}$.

Table 6. Mean values for net assimilation (A, $\left.\mu \mathrm{mol} \mathrm{CO}_{2} \mathrm{~m}^{-2} \mathrm{~s}^{-1}, n=3-6\right)$, transpiration ( $\left.\mathrm{Tr}, \mathrm{mmol} \mathrm{H}_{2} \mathrm{O} \mathrm{m}^{-2} \mathrm{~s}^{-1}, n=3-6\right)$, water use efficiency (WUE, mmol CO $\left.\mathrm{mol}^{-1} \mathrm{H}_{2} \mathrm{O}, n=3-6\right)$, and stomatal conductance $\left(\mathrm{g}_{\mathrm{s}}, \mathrm{mol} \mathrm{H}_{2} \mathrm{O} \mathrm{m}^{-2} \mathrm{~s}^{-1}, n=3-6\right)$ at $1500 \mu \mathrm{mol} \mathrm{m}{ }^{-2} \mathrm{~s}^{-1}$ for different height levels. Numbers in parentheses are SD.

\begin{tabular}{cccc}
\hline PAR $=\mathbf{1 5 0 0} \mu \mathbf{m o l ~ m}^{-\mathbf{2}} \mathbf{s}^{-\mathbf{1}}$ & Lower $\left(\mathbf{z}_{\mathbf{L}}\right)$ & Middle $\left(\mathbf{z}_{\mathbf{M}}\right)$ & Higher $\left(\mathbf{z}_{\mathbf{H}}\right)$ \\
\hline $\mathrm{A}\left(\mu \mathrm{mol} \mathrm{CO} \mathrm{m}^{-2} \mathrm{~s}^{-1}\right)$ & $12.05(3.01)$ & $21.30(2.92)$ & $18.10(4.89)$ \\
$\operatorname{Tr}\left(\mathrm{mmol} \mathrm{H}_{2} \mathrm{O} \mathrm{m}^{-2} \mathrm{~s}^{-1}\right)$ & $2.51(0.43)$ & $2.24(0.97)$ & $2.98(0.47)$ \\
$\mathrm{WUE}\left(\mathrm{mmol} \mathrm{CO}_{2} \mathrm{~mol}^{-1} \mathrm{H}_{2} \mathrm{O}\right)$ & $4.73(0.55)$ & $12.99(9.28)$ & $6.10(2.13)$ \\
$g_{s}\left(\mathrm{~mol} \mathrm{H}_{2} \mathrm{O} \mathrm{m}^{-2} \mathrm{~s}^{-1}\right)$ & $0.13(0.03)$ & $0.17(0.04)$ & $0.18(0.05)$ \\
\hline
\end{tabular}

\section{Discussion}

\subsection{Isoprene Emissions, Net Assimilation, and Water Use Efficiency}

As expected, isoprene was the dominant compound throughout the growing season and made up 90-99\% of the total BVOC emission, with measured emission rates reaching up to $150 \mu \mathrm{g} \mathrm{g}_{\mathrm{dw}}{ }^{-1} \mathrm{~h}^{-1}$. The STD isoprene emission rate averaged over the whole study (45.2 $\left.\mu \mathrm{g} \mathrm{g}_{\mathrm{dw}}{ }^{-1} \mathrm{~h}^{-1}\right)$ is comparable to what has been shown in other studies $[13,58,59]$. However, the reported range of STD isoprene emission rates is wide [13,59]. In Morrison et al. [59], the STD isoprene emission for unknown Salix spp. varieties varied from 0.1 to $15.9 \mu \mathrm{g} \mathrm{g}_{\mathrm{dw}}{ }^{-1} \mathrm{~h}^{-1}$ for three different sites in the United Kingdom. In their study, a similar method was used as in this study but since they included the whole year, a lower emission can be expected on account of the low temperature and PAR during the non-peak season. Moreover, the age of the measured trees was not the same in their study (first, second, and third growing season) as in this study (third and fourth growing season). Another study done close to our site reported a ca 6 times lower STD isoprene emission from clones that originated from the same species (S. viminalis) as was measured in this study, during peak summer [44]. In their study, a relaxed eddy accumulation technique scaled by foliar mass density was used, which is a different method compared with the methods used in this study and could therefore explain the disparity. In particular, this method includes measurements from the whole canopy, i.e., both sun-exposed and shaded leaves, whereas most leaves in this study were adapted to sunlit conditions. Additionally, emission rates vary within the same species [13], which can explain why the average STD isoprene emission in 2015 was twice as high as in 2016, despite similar $\mathrm{T}_{C}$ and $P A R_{C}$, since the plantations contained different varieties. According to Karlsson et al. [42], it has been shown that Salix varieties growing on SRC fields emit various amounts of isoprene and that the Tora-variety growing on P2 is a low emitter.

The seasonal patterns for isoprene emissions in the two Salix varieties we measured in 2015 and 2016 were similar. The highest emission rates typically occurred when weather was warm and sunny. The measurements in 2016 showed that the trees were able to emit high rates of isoprene already in the beginning of May. At this point, the weather had started to become warmer, which resulted in the trees developing small leaves with a light green color. It is well known that isoprene emission is influenced by temperature because of the linkage to the enzyme isoprene synthase [60,61]. In September, measured and STD isoprene emissions during 2015 and 2016 started to decline compared with the former months. In October 2016, isoprene emissions were negligible. The reason for the declining trend is mostly explained by changing weather (2015), and the approaching fall and leaf senescence [62,63]. In particular, all isoprene emissions were $<3.0 \mu \mathrm{g} \mathrm{g}_{\mathrm{dw}}{ }^{-1} \mathrm{~h}^{-1}$ and most of the samples contained no isoprene during October. Zero emissions of isoprene occurred when $\mathrm{T}_{\mathrm{C}}$ was ca $11^{\circ} \mathrm{C}$ or lower, and $\mathrm{PAR}_{\mathrm{C}}<110 \mu \mathrm{mol} \mathrm{m}{ }^{-2} \mathrm{~s}^{-1}$, indicating that these values 
could be a threshold for isoprene emission during late season for this location and variety. These growing conditions in combination with the leaf damage caused by P. vulgatissima explain why the isoprene emissions from $z_{\mathrm{H}}$ were exceptionally low in October since many leaves at $\mathrm{z}_{\mathrm{H}}$ were almost gone and more or less only the midrib was left (Figure S3).

The Melampsora infestation on P1 likely affected the emission rates. Toome et al. [64] showed that willow trees infected with Melampsora reduced their isoprene emission rates by almost 30\% and a similar result was observed for Populus [65]. Perhaps, the isoprene emissions would have been even higher in 2015 if no Melampsora outbreak had occurred.

Measured and STD isoprene emissions from the more sunlit leaves $\left(z_{H}\right)$ exceeded emission rates from shaded leaves $\left(z_{L}\right)$ as expected $[45,66,67]$. Previous studies have reported a hyperbolic curve for isoprene when PAR increases $[55,68,69]$, which can be linked to the photosynthetic electron transport $[69,70]$, and a similar behavior was observed in this study. Isoprene emissions from sun-adapted leaves at $\mathrm{z}_{\mathrm{H}}$ responded faster to increased light, and reached twice as high maximum emission rates. This result is in line with Sharkey et al. [66], who studied isoprene emissions from oak and aspen, and it also points out that large errors can be expected if up-scaled emissions are based on data from only one canopy height [45].

The isoprene emission increased exponentially with temperature but it is hard to state if the optimum temperature was reached in our study. In a subarctic Salix myrsinites, isoprene emission increased exponentially across the temperature range of $10-38{ }^{\circ} \mathrm{C}$ without reaching a maximum [71]. According to Niinemets et al. [72], the optimum often occurs around $40^{\circ} \mathrm{C}$, suggesting that this could be the same for the varieties in this study. Nevertheless, measurements at higher temperatures are needed to confirm this.

The net assimilation was higher for $\mathrm{z}_{\mathrm{H}}$ compared with $\mathrm{z}_{\mathrm{L}}$, but lower than for $\mathrm{z}_{\mathrm{M}}$. An increasing A pattern with canopy height has been reported previously [73,74]. Since also $\mathrm{Tr}$ from $z_{M}$ was below the others, this resulted in a higher WUE for $z_{M}$, making these leaves more efficient in their water use than the leaves at $z_{L}$ and $z_{H}$. The $E / A$ ratio at $z_{H}$ exceeded that at $z_{L}$, which means that the light-adapted leaves in the upper part of the canopy lose more $\mathrm{C}$ as isoprene than less light-adapted leaves. However, despite the lower isoprene emission rates from the shaded leaves at $z_{L}$, they showed a strong increase (ca $\left.50 \%\right)$ in their E/A ratio when PAR increased from 1000 to $1500 \mu \mathrm{mol} \mathrm{m}^{-2} \mathrm{~s}^{-1}$. So, even for leaves less acclimatized to sunlight, isoprene serves as a strongly induced compound when the leaves are light-stressed. The leaves that were more sun-adapted $\left(\mathrm{z}_{\mathrm{H}}\right.$ and $\left.\mathrm{z}_{\mathrm{M}}\right)$ did not show this pattern.

Measurements of A and simultaneously emitted BVOCs showed that the trees only used a minor fraction $(0.4 \%)$ of photosynthetic C for BVOC emission, although compounds with less than five carbon units (i.e., methanol, acetone) were not detectable with the methods used in this study. This ratio is comparable with the results from a study conducted during summer on a spruce forest, where the assimilated $C$ loss on average was approximately $0.3 \%$ [75]. For isoprene, the ratio between emitted $\mathrm{C}$ and $\mathrm{A}$ was similar to what had been found for some species of poplar [76], which are also known to be high isoprene emitters. Only a small percentage of the net carbon assimilation is in general released as BVOCs [77-80] but under stressed conditions, carbon loss can be 7-8\% due to increased isoprene emissions [68,81].

The maximum A for the sunlit leaves is in line with results in other studies, which suggest that A for Salix trees can vary between 10 to $35 \mu \mathrm{mol} \mathrm{CO}_{2} \mathrm{~m}^{-2} \mathrm{~s}^{-1}[42,82]$. The WUE values for $z_{L}$ and $z_{H}$ were comparable with the values for Tora reported in Karlsson et al. [42].

The variety Tora in Karlsson et al. [42] had a ca 80\% lower STD isoprene emission compared with Tora on P2 when comparing the leaf chamber measurements for sunadapted leaves. This difference is probably due to the fact that the trees were younger (first and second growing season) in Karlsson et al. [42]. 
Changing from traditional crops, e.g., wheat, rye, oat, or oilseed rape, which are low emitters of isoprene $[59,83-85]$ to a SRC (e.g., willow) would drastically alter the regional concentration of isoprene and increase the risk of $\mathrm{O}_{3}$ production near polluted areas [86-88].

\subsection{Emissions of Monoterpenes, Sesquiterpenes, and Other Volatile Organic Compounds}

The second most emitted compound was ocimene and together with $\alpha$-pinene, they contributed with more than $95 \%$ to the MT emission throughout 2015. In 2016, ocimene dominated over the other MTs, followed by limonene, p-cymene, and linalool. Even if the emission rates of the MTs varied individually during the season, both 2015 and 2016 showed the same trend, where the measured average total emission of MTs decreased across the measurement periods, but occasional higher emissions were still possible in late summer and autumn. Emissions of MTs can be dependent on the season and willow leaves have shown a stronger capacity to emit MTs in the beginning of the growing season close to bud break $[59,89]$. However, we cannot verify this suggestion as we did not measure in early spring. The most abundant SQTs were caryophyllene, humulene, and $\alpha$-farnesene. The emissions of these compounds peaked in the second part of the growing season between July and September. No SQTs could be observed during May and October.

Ocimene and $\alpha$-farnesene were the only terpenes, besides isoprene, that were influenced by PAR. Ocimene was also found to increase with light by Karlsson et al. [42]. Many studies have shown a correlation between terpenes and light [42,90-92]. This similarity with isoprene shows that emissions of some MTs and SQTs could be described by a similar light- and temperature-dependent algorithm developed by Guenther et al. [55] for short-term emissions.

Shade-adapted leaves at $z_{L}$ emitted less MTs and had lower emission rates than the sun-adapted leaves at $z_{H}$ but the emissions from $z_{M}$ were higher than $z_{H}$ in May and October. The only month when the SQT emission from the lower height $\left(\mathrm{z}_{\mathrm{M}}\right)$ exceeded that from the higher height level $\left(\mathrm{z}_{\mathrm{H}}\right)$ was in August. Neither ocimene nor $\alpha$-farnesene were emitted from $z_{L}$, which suggests that the leaves require an adaption to an environment with sufficient sunlight to be able to emit these terpenes. Monoterpenes and SQTs are very reactive and protect the plant against different abiotic and biotic stresses [49,93-100].

Several times higher emissions of other VOCs were observed in August 2015 compared with the other months this year. The compounds responsible for these emission rates (e.g., benzaldehyde, nonanal, octanal, decanal, and hexanal) have been reported to be induced during abiotic and biotic stresses [65,101-104]. Jiang et al. [65] reported induced emissions of nonanal and decanal from Populus leaves infested by Melampsora. Toome et al. [64] also studied the impact of Melampsora and showed that an infection on willow trees resulted in increased emission of some GLVs (e.g., (Z)-3-hexenol and (E)-2-hexenal), as well as (Z)- $\beta$ ocimene and (E,E)- $\alpha$-farnesene. Moreover, Arimura et al. [105] observed stress-induced emissions of (E)- $\beta$-ocimene, linalool, and (E,E)- $\alpha$-farnesene from poplar leaves eaten by caterpillar. The higher emissions of $\alpha$-farnesene and caryophyllene might have been a consequence of the Melampsora infestation (2015) and herbivore insects (2016).

Emissions of other VOCs were larger from the lower canopy height compared with the higher canopy height, but it is difficult to pinpoint the underlying reason. If the leaves were more attractive to leaf-eating insects at the upper canopy, one would expect higher emission rates from this level as a self-defending mechanism [94,106]. On the other hand, the higher emission rates from the lower canopy could be the reason why these beetles strike the upper part. However, one explanation for the difference might be related to how the leaves looked. In July and August, the leaves at the lower height were smaller with a brighter green color compared with the higher height. Further, the damage by $P$. vulgatissima is believed to have reduced the emission from the upper part of the canopy, especially in October.

Most studies have only focused on isoprene and a few other compounds, which usually are most abundant $[43,59,107,108]$. Even if isoprene is dominant and crucial for air chemistry processes, other compounds might also be of importance. Monoterpenes 
constitute a group responsible for particle formation and generation of SOAs [38,109]. Additionally, stress-induced compounds are usually not included (yet) in modeling processes, but biogenic non-terpenoids can contribute with the same magnitude as anthropogenic sources of non-terpenoids to SOA formation and should not be discarded [104].

\section{Summary and Conclusions}

We studied seasonal trends and canopy height differences for BVOC emissions of willow varieties growing as bioenergy crops on SRC fields. The majority of the measurements in 2015 were done on an unknown variety belonging to $S$. viminalis, while all measurements in 2016 were on the variety Tora. The results from this study confirm that isoprene was the most dominant BVOC during the major part of the growing season. Emissions of MTs, SQTs, and other VOCs were in general only a minor fraction of the total BVOC emission. The prevailing infestation of Melampsora (2015) was probably responsible for increased emissions of, e.g., nonanal, hexanal, and caryophyllene.

The emissions of isoprene peaked during summer (in July 2015 and in August 2016) but the leaves had high emissions already in May. The seasonal pattern for SQTs showed that these peaked during summer as well. Emissions of MTs showed a decreasing trend from May to October and the overall terpenoid emission seemed to be substantially lower by the end of the growing season as a consequence of colder weather and proceeding leaf senescence.

Our study suggests that Tora is a better choice when it comes to having a reduced risk for impaired air quality since it emitted ca $50 \%$ less isoprene, which can be a source for $\mathrm{O}_{3}$ and peroxyacetyl nitrate. Nevertheless, Salix trees are high emitters of isoprene compared with commercial crops, and an expansion of Salix plantations would need to be strategically planned and placed at a sufficiently long distance away from pollution sources to avoid elevated photochemical production of $\mathrm{O}_{3}$ under high $\mathrm{NO}_{\mathrm{x}}$ conditions.

Leaves higher up in the canopy and acclimatized to more sunlight emitted higher rates of isoprene than the leaves growing in the lower and more shaded parts of the canopy. Emissions of MTs were also lower for the leaves in the shaded conditions and no SQT emissions were observed from the shade-adapted leaves. On the contrary, emissions of non-terpenoids were higher from the lower part of the canopy. These results point out that the location within the canopy is one important factor when it comes to emissions of different compounds, particularly those compounds that are dependent on PAR. Hence, to make better estimations of the regional and global BVOC fluxes, models need to adjust for, e.g., the vertical distribution of leaf area within the canopy layer.

Ocimene and $\alpha$-farnesene were the only compounds, except isoprene, that were influenced by light, suggesting that they can be modeled with a similar algorithm as isoprene.

This study highlights that scaling-up BVOC emissions and basing models on one simplified emission potential for the whole canopy could lead to large errors.

Supplementary Materials: The following are available online at https:/ / www.mdpi.com/article/10 .3390 /atmos12111427/s1, Figure S1: Photos of the two plots. Figure S2: Photos of Melampsora-infested leaves. Figure S3: Photos of leaves in October. Table S1: Injected standards in GC-MS. Table S2: Average emission values for all detected compounds. Table S3: Average emission, $\mathrm{T}_{\mathrm{C}}$ and $\mathrm{PAR}_{\mathrm{C}}$ for each month of 2015. Table S4: Parameter values for fitted isoprene curves in Figure 3. Table S5: Slope and parameter values for fitted curves in Figure 4A. Figure S4: STD isoprene emission vs. PAR. Table S6: Parameter values for fitted isoprene curves in Figure S4. Table S7: Parameter values for fitted E/A curves in Figure 4B. Figure S5: Total average BVOC emission and fraction vs. PAR at $\mathrm{z}_{\mathrm{M}}$. Table S8: Parameter values for fitted emission curves in Figure 6A,B. Table S9: Slope values for A in Figure 7A. Table S10: Parameter values for fitted A curves in Figure 7A.

Author Contributions: Conceptualization, T.H. and T.K.; methodology, T.H.; software, T.H.; validation, T.K. and T.H.; formal analysis, T.K.; investigation, T.K.; data curation, T.K., T.H. and R.R.; resources, T.H., R.R. and L.K; writing—original draft preparation, T.K.; writing—review and editing, T.K., R.R., L.K. and T.H.; supervision T.H.; project administration, T.K. and T.H.; funding acquisition, T.H. All authors have read and agreed to the published version of the manuscript. 
Funding: This study was partly financed by the Swedish Research Council for Sustainable Development (FORMAS) under grant 2012-727.

Institutional Review Board Statement: Not applicable.

Informed Consent Statement: Not applicable.

Data Availability Statement: Data from this study is available from the corresponding author upon reasonable request.

Acknowledgments: We thank Swedish Infrastructure for Ecosystem Science (SITES) for the logistic support. Additionally, we thank Anders Jonsson and Per-Olof Andersson in Grästorp for their permission to conduct measurements and helping out at the site.

Conflicts of Interest: The authors declare no conflict of interest. The funders had no role in the design of the study; in the collection, analyses, or interpretation of data; in the writing of the manuscript; or in the decision to publish the results.

\section{References}

1. A Policy Framework for Climate and Energy in the Period from 2020 up to 2030; European Commission: Brussels, Belgium, 2014.

2. IPCC. 2021: Summary for Policymakers. In Climate Change 2021: The Physical Science Basis. Contribution of Working Group I to the Sixth Assessment Report of the Intergovernmental Panel on Climate Change; Masson-Delmotte, V., Zhai, P., Pirani, A., Connors, S.L., Péan, C., Berger, S., Caud, N., Chen, Y., Goldfarb, L., Gomis, M.I., et al., Eds.; Cambridge University Press: Cambridge, UK, 2021; In press.

3. Bonde, I.; Kuylenstierna, J.; Bäckstrand, K.; Eckerberg, K.; Kåberger, T.; Löfgren, Å.; Rummukainen, M.; Sörlin, S. 2020-Report of the Swedish Climate Policy Council; Rapport nr 3; Swedish Climate Policy Council: Stockholm, Sweden, 2020; ISBN 978-91-984671-4-7.

4. Don, A.; Osborne, B.; Hastings, A.; Skiba, U.; Carter, M.S.; Drewer, J.; Flessa, H.; Freibauer, A.; Hyvönen, N.; Jones, M.B.; et al. Land-use change to bioenergy production in Europe: Implications for the greenhouse gas balance and soil carbon. Glob. Chang. Biol. Bioenergy 2011, 4, 372-391. [CrossRef]

5. Lindegaard, K.N.; Adams, P.W.; Holley, M.; Lamley, A.; Henriksson, A.; Larsson, S.; von Engelbrechten, H.G.; Esteban Lopez, G.; Pisarek, M. Short rotation plantations policy history in Europe: Lessons from the past and recommendations for the future. Food Energy Secur. 2016, 5, 125-152. [CrossRef]

6. Kimming, M.; Sundberg, C.; Nordberg, Å.; Baky, A.; Bernesson, S.; Norén, O.; Hansson, P.A. Biomass from agriculture in small-scale combined heat andpower plants-A comparative life cycle assessment. Biomass Bioenerg. 2011, 35, $1572-1581$. [CrossRef]

7. Åhman, I.; Larsson, S. Resistensförädling i Salix för Energiproduktion, SLU; Institutionen för entomologi, Nr/avsnitt: 2; SLU: Alnarp, Sweden, 1999.

8. Kägi, T.; Deimling, S.; Knuchel, R.F.; Gaillard, G.; Hölscher, T.; Müller-Sämann, K. Environmental impacts of annual and perennial energy crops compared to a reference foo crop rotation. In Proceedings of the Empowerment of the Rural Actors: A Renewal of Farming Systems Perspectives 8th European IFSA Symposium, Clermont-Ferrand, Clermont-Ferrand, France, 6-10 July 2008; pp. 675-681.

9. Fredga, K.; Danell, K.; Frank, H.; Hedberg, D.; Kullander, S. Bioenergy-Opportunities and constraints. In Energy Committee Report; Kungliga Vetenskapsakademin: Stockholm, Sweden, 2008.

10. Landberg, T.; Greger, M. Differences in uptake and tolerance to heavy metals in Salix from unpolluted and polluted areas. Appl. Geochem. 1996, 11, 175-180. [CrossRef]

11. Meers, E.; Vandecasteele, B.; Ruttens, A.; Vangronsveld, J.; Tack, F. Potential of five willow species (Salix spp.) for phytoextraction of heavy metals. Environ. Exp. Bot. 2007, 60, 57-68. [CrossRef]

12. SOU 2007:36. Bioenergi från Jordbruket-en Växande Resurs; Statens Offentliga Utredningar; Edita Sverige AB: Stockholm, Sweden, 2007; ISBN 978-91-38-22751-0.

13. Kesselmeier, J.; Staudt, M. Biogenic volatile organic compounds (VOC): An overview on emission, physiology and ecology. J. Atmos. Chem. 1999, 33, 23-88. [CrossRef]

14. Dicke, M.; Vet, L.E.M. Plant-carnivore carnivore interactions: Evolutionary and ecological consequences for plant, herbivore and carnivore. In Herbivores: Between Plants and Predators; Olff, H., Brown, V.K., Drent, R.H., Eds.; Blackwell Science: Oxford, UK, 1999; pp. $483-520$.

15. Llusià, J.; Peñuelas, J. Emission of volatile organic compounds by apple trees in response to spider mite attack and attraction of predatory mites. Exp. Appl. Acarol. 2001, 25, 65-77. [CrossRef] [PubMed]

16. Dicke, M.; van Poecke, R.M.P.; de Boer, J.G. Inducible indirect defence of plants: From mechanisms to ecological functions. Basic Appl. Ecol. 2003, 4, 27-42. [CrossRef]

17. Dudareva, N.; Pichersky, E. Metabolic engineering of plant volatiles. Curr. Opin. Biotechnol. 2008, 19, 1-9. [CrossRef]

18. Laothawornkitkul, J.; Taylor, J.; Paul, N.; Hewitt, C. Biogenic volatile organic compounds in the Earth system. New Phytol. 2009, 183, 27-51. [CrossRef] 
19. Possell, M.; Loreto, F. The role of volatile organic compounds in plant resistance to abiotic stresses: Responses and mechanisms. In Biology, Controls and Models of Tree Volatile Organic Compound Emissions; Niinemets, Ü., Monson, R.K., Eds.; Tree Physiology; Springer: Berlin/Heidelberg, Germany, 2013; Volume 5, pp. 209-235.

20. Folberth, G.A.; Hauglustaine, D.A.; Lathière, J.; and Brocheton, F. Interactive chemistry in the Laboratoire de Météorologie Dynamique general circulation model: Model description and impact analysis of biogenic hydrocarbons on tropospheric chemistry. Atmos. Chem. Phys. 2006, 6, 2273-2319. [CrossRef]

21. Arneth, A.; Monson, R.K.; Schurgers, G.; Niinemets, Ü.; Palmer, P.I. Why are estimates of global terrestrial isoprene emissions so similar (and why is this not so for monoterpenes)? Atmos. Chem. Phys. 2008, 8, 4605-4620. [CrossRef]

22. Calfapietra, C.; Fares, S.; Manes, F.; Morani, A.; Sgrigna, G.; Loreto, F. Role of biogenic volatile organic compounds (BVOC) emitted by urban trees on ozone concentration in cities: A review. Environ. Pollut. 2013, 183, 71-80. [CrossRef] [PubMed]

23. Chameides, W.L.; Lindsay, R.W.; Richardson, J. The Role of Biogenic Hydrocarbons in Urban Photochemical Smog: Atlanta as a Case Study. Science 1988, 241, 1473-1475. [CrossRef]

24. Ryerson, T.B.; Trainer, M.; Holloway, J.S.; Parrish, D.D.; Huey, L.G.; Sueper, D.T.; Frost, G.J.; Donnelly, S.G.; Schauffler, S.; Atlas, E.L.; et al. Observations of Ozone Formation in Power Plant Plumes and Implications for Ozone Control Strategies. Science 2001, 292, 719. [CrossRef] [PubMed]

25. Kleinman, L.I.; Daum, P.H.; Imre, D.; Lee, Y.-N.; Nunnermacker, L.J.; Springston, S.R.; Weinstein-Lloyd, J.; Rudolph, J. Ozone production rate and hydrocarbon reactivity in 5 urban areas: A cause of high ozone concentration in Houston. Geophys. Res. Lett. 2002, 29, 105-1-105-4. [CrossRef]

26. Fares, S.; Barta, C.; Ederli, L.; Ferranti, F.; Pasqualini, S.; Reale, L.; Brilli, F.; Tricoli, D.; Loreto, F. Impact of high ozone on isoprene emission and some anatomical and physiological parameters of developing Populus alba leaves directly or indirectly exposed to the pollutant. Physiol. Plant. 2006, 128, 456-465. [CrossRef]

27. Wittig, V.E.; Ainsworth, E.A.; Naidu, S.L.; Karnoski, D.F.; Long, S.P. Quantifying the impact of current and future tropospheric ozone on tree biomass, growth, physiology and biochemistry: A quantitative meta-analysis. Glob. Chang. Biol. 2009, 15, 396-424. [CrossRef]

28. Kurpius, M.R.; Goldstein, A.H. Gas-phase chemistry dominates O3 loss to a forest, implying a source of aerosols and hydroxyl radicals to the atmosphere. Geophys. Res. Lett. 2003, 30, 1371. [CrossRef]

29. Agyei, T.; Juráň, S.; Kwakye, K.O.; Šigut, L.; Urban, O.; Marek, M.V. The impact of drought on total ozone flux in a mountain Norway spruce forest. J. For. Sci. 2020, 66, 280-287. [CrossRef]

30. Ashmore, M.R. Assessing the future global impacts of ozone on vegetation. Plant Cell Environ. 2005, 28, 949-964. [CrossRef]

31. Sitch, S.; Cox, P.M.; Collins, W.J.; Huntingford, C. Indirect radiative forcing of climate change through ozone effects on the land-carbon sink. Nature 2007, 448, 791-794. [CrossRef] [PubMed]

32. Hoffmann, T.; Odum, J.R.; Bowman, F.; Collins, D.; Klockow, D.; Flagan, R.C.; Seinfeld, J.H. Formation of organic aerosols from the oxidation of biogenic hydrocarbons. J. Atmos. Chem. 1997, 26, 189-222. [CrossRef]

33. O’Dowd, C.D.; Jimenez, J.L.; Bahreini, R.; Flagan, R.C.; Seinfeld, J.H.; Hämeri, K.; Pirjola, L.; Kulmala, M.; Jennings, S.G.; Hoffmann, T. Marine aerosol formation from biogenic iodine emissions. Nature 2002, 417, 497-501. [CrossRef]

34. Claeys, M.; Graham, B.; Vas, G.; Wang, W.; Vermeylen, R.; Pashynska, V.; Cafmeyer, J.; Guyon, P.; Andreae, M.O.; Artaxo, P.; et al. Formation of secondary organic aerosols through photooxidation of isoprene. Science 2004, 303, 1173-1176. [CrossRef] [PubMed]

35. Kulmala, M.; Suni, T.; Lehtinen, K.E.J.; Dal Maso, M.; Boy, M.; Reissell, A.; Rannik, Û.; Aalto, P.; Keronen, P.; Hakola, H.; et al. A new feedback mechanism linking forests, aerosols, and climate. Atmos. Chem. Phys. 2004, 4, 557-562. [CrossRef]

36. VanReken, T.M.; Greenberg, J.P.; Harley, P.C.; Guenther, A.B.; Smith, J.N. Direct measurement of particle formation and growth from the oxidation of biogenic emissions. Atmos. Chem. Phys. 2006, 6, 4403-4413. [CrossRef]

37. Spracklen, D.V.; Bonn, B.; Carslaw, K.S. Boreal forests, aerosols and the impacts on clouds and climate. Philos. Trans. R. Soc. A 2008, 366, 4613-4626. [CrossRef]

38. Paasonen, P.; Asmi, A.; Petäjä, T.; Kajos, M.K.; Äijälä, M.; Junninen, H.; Holst, T.; Abbatt, J.P.D.; Arneth, A.; Birmili, W.; et al. Warming-induced increase in aerosol number concentration likely to moderate climate change. Nat. Geosci. 2013, 6, 438-442. [CrossRef]

39. Ehn, M.; Thornton, J.A.; Kleist, E.; Sipilä, M.; Junninen, H.; Pullinen, I.; Springer, M.; Rubach, F.; Tillmann, R.; Lee, B.; et al. A large source of low-volatility secondary organic aerosol. Nature 2014, 506, 476-479. [CrossRef]

40. Boucher, O.; Randall, P.D.; Artaxo, C.; Bretherton, G.; Feingold, P.; Forster, V.-M.; Kerminen, Y.; Kondo, H.; Liao, U.; Lohmann, P.; et al. 2013: Clouds and Aerosols. In Climate Change 2013: The Physical Science Basis. Contribution of Working Group I to the Fifth Assessment Report of the Intergovernmental Panel on Climate Change; Stocker, T.F., Qin, D., Plattner, G.-K., Tignor, M., Allen, S.K., Boschung, J., Nauels, A., Xia, Y., Bex, V., Midgley, P.M., Eds.; Cambridge University Press: Cambridge, UK; New York, NY, USA, 2013.

41. Vedel-Petersen, I.; Schollert, M.; Nymand, J.; Rinnan, R. Volatile organic compound emission profiles of four common arctic Plants. Atmos. Environ. 2015, 120, 117-126. [CrossRef]

42. Karlsson, T.; Rinnan, R.; Holst, T. Variability of BVOC Emissions from Commercially Used Willow (Salix spp.) Varieties. Atmosphere 2020, 11, 356. [CrossRef]

43. Owen, S.M.; Boissard, C.; Hewitt, C.N. Volatile organic compounds (VOCs) emitted from 40 Mediterranean plant species: VOC speciation and extrapolation to habitat scale. Atmos. Environ. 2001, 35, 5393-5409. [CrossRef] 
44. Olofsson, M.; Ekolausson, B.; Jensen, N.; Langer, S.; Ljungström, E. The flux of isoprene from a willow coppice plantation and the effect on local air quality. Atmos. Environ. 2005, 39, 2061-2070. [CrossRef]

45. Niinemets, Ü.; Copolovici, L.; Hüve, K. High within-canopy variation in isoprene emission potentials in temperate trees: Implications for predicting canopy-scale isoprene fluxes. J. Geophys. Res. 2010, 115, G04029. [CrossRef]

46. Persson, Y.; Schurgers, G.; Ekberg, A.; Holst, T. Effects of intra-genotypic variation, variance with height and time of season on BVOC emissions. Meteorol. Z. 2016, 25, 377-388. [CrossRef]

47. Alexandersson, H.; Eggertsson Karlström, C. Temperaturen och nederbörden i Sverige 1961-90: Referensnormaler-utgåva 2. Meteorologi 99; Swedish Meteorological and Hydrological Institute: Norrköping, Sweden, 2001. (In Swedish)

48. SGU, Geology Survey of Sweden. Available online: http:/ / maps-test.sgu.se:8080/TestSguMapViewer2/kartvisare-lerhaltskartasv.html (accessed on 7 March 2019).

49. Haapanala, S.; Ekberg, A.; Hakola, A.; Tarvainen, V.; Rinne, J.; Hellén, H.; Arneth, A. Mountain birch-Potentially large source of sesquiterpenes into high latitude atmosphere. Biogeosciences 2009, 6, 2709-2718. [CrossRef]

50. van Meeningen, Y.; Wang, M.; Karlsson, T.; Seifert, A.; Schurgers, G.; Rinnan, R.; Holst, T. Isoprenoid emission variation of Norway spruce across a European latitudinal transect. Atmos. Environ. 2017, 170, 45-57. [CrossRef]

51. Wang, M.; Schurgers, G.; Arneth, A.; Ekberg, A.; Holst, T. Seasonal variation in biogenic volatile organic compound (BVOC) emissions from Norway spruce in a Swedish boreal forest. Boreal Environ. Res. 2017, 22, 353-367.

52. van Meeningen, Y.; Schurgers, G.; Rinnan, R.; Holst, T. Isoprenoid emission response to changing light conditions of English oak, European beech and Norway spruce. Biogeosciences 2017, 14, 4045-4060. [CrossRef]

53. Lindwall, F.; Svendsen, S.S.; Nielsen, C.S.; Michelsen, A.; Rinnan, R. Warming in-creases isoprene emissions from an arctic fen Sci. Total Environ. 2016, 553, 297-304. [CrossRef] [PubMed]

54. Ortega, J.; Helmig, D. Approaches for quantifying reactive and low-volatility biogenic organic compound emissions by vegetation enclosure techniques-Part A. Chemosphere 2008, 72, 343-364. [CrossRef]

55. Guenther, A.B.; Zimmerman, P.; Harley, P.C.; Monson, R.K.; Fall, R. Isoprene and monoterpene emission rate variability: Model evaluations and sensitivity analyses. J. Geophys. Res. 1993, 98, 12609-12617. [CrossRef]

56. Helmig, D.; Ortega, J.; Duhl, T.; Tanner, D.; Guenther, A.; Harley, P.; Wiedinmyer, C.; Milford, J.; Sakulyanontvittaya, T. Sesquiterpene Emissions from Pine Trees-Identifications, Emission Rates and Flux Estimates for the Contiguous United States. Environ. Sci. Technol. 2007, 41, 1545-1553. [CrossRef] [PubMed]

57. Niinemets, Ü.; Sun, Z.; Talts, E. Controls of the quantum yield and saturation light of isoprene emission in different-aged aspen leaves. Plant Cell Environ. 2015, 38, 2707-2720. [CrossRef] [PubMed]

58. Owen, S.M.; Hewitt, C.N. Extrapolating branch enclosure measurements to estimates of regional scale biogenic VOC fluxes in the north-western Mediterranean basin. J. Geophys. Res. 2000, 105, 11573-11583. [CrossRef]

59. Morrison, E.C.; Drewer, J.; Heal, M.R. A comparison of isoprene and monoterpene emission rates from the perennial bioenergy crops short-rotation coppice willow and Miscanthus and the annual arable crops wheat and oilseed rape. GCB Bioenergy 2016, 8 , 211-225. [CrossRef]

60. Monson, R.K.; Jaeger, C.H.; Adams, W.; Driggers, E.; Silver, G.; Fall, R. Relationships among isoprene emission rate, photosynthesis rate, and isoprene synthase activity, as influenced by temperature. Plant Physiol. 1992, 92, 1175-1180. [CrossRef]

61. Kuzma, J.; Fall, R. Leaf isoprene emission rate is dependent on leaf development and the level of isoprene synthase. Plant Physiol. 1993, 101, 435-440. [CrossRef]

62. Monson, R.K.; Harley, P.C.; Litvak, M.E.; Wildermuth, M.; Guenther, A.B.; Zimmerman, P.R.; Fall, R. Environmental and developmental controls over the seasonal pattern of isoprene emission from aspen leaves. Oecologia 1994, 99, 260-270. [CrossRef]

63. Schnitzler, J.-P.; Lehning, A.; Steinbrecher, R. Seasonal Pattern of Isoprene Synthase Activity in Quercus robur Leaves and its Significance or Modeling Isoprene Emission Rates. Bot. Acta 1997, 110, 240-243. [CrossRef]

64. Toome, M.; Randjärv, P.; Copolovici, L.; Niinemets, Ü.; Heinsoo, K.; Luik, A.; Noe, S.M. Leaf rust induced volatile organic compounds signalling in willow during the infection. Planta 2010, 232, 235-243. [CrossRef]

65. Jiang, Y.; Ye, J.; Veromann, L.-L.; Niinemets, Ü. Scaling of photosynthesis and constitutive and induced volatile emissions with severity of leaf infection by rust fungus (Melampsora larici-populina) in Populus balsamifera var. suaveolens. Tree Physiol. 2016, 36, 856-872. [CrossRef] [PubMed]

66. Sharkey, T.D.; Loreto, F.; Delwiche, C.F. High carbon dioxide and sun/shade effects on isoprene emission from oak and aspen tree leaves. Plant Cell Environ. 1991, 14, 333-338. [CrossRef]

67. Lerdau, M.; Throop, H.L. Sources of variability in isoprene emission and photosynthesis in two species of tropical wet forest trees. Biotropica 2000, 32, 670-676. [CrossRef]

68. Monson, R.K.; Fall, R. Isoprene emission from aspen leaves. Plant Physiol. 1989, 90, 267-274. [CrossRef] [PubMed]

69. Guenther, A.B.; Monson, R.K.; Fall, R. Isoprene and monoterpene emission rate variability: Observations with eucalyptus and emission rate algorithm development. J. Geophys. Res. 1991, 96, 10799-10808. [CrossRef]

70. Sharkey, T.D.; Monson, R.K. Isoprene research-60 years later, the biology is still enigmatic. Plant Cell Environ. 2017, 40, 1671-1678. [CrossRef]

71. Simin, T.; Tang, J.; Holst, T.; Rinnan, R. Volatile organic compound emission in tundra shrubs-Dependence on species characteristics and the near-surface environment. Environ. Exp. Bot. 2021, 184, 104387. [CrossRef] 
72. Niinemets, Ü.; Tenhunen, J.D.; Harley, P.C.; Steinbrecher, R. A model of isoprene emission based on energetic requirements for isoprene synthesis and leaf photosynthetic properties for Liquidambar and Quercus. Plant Cell Environ. 1999, 22, 1319-1335. [CrossRef]

73. Kenzo, T.; Ichie, T.; Watanabe, Y.; Yoneda, R.; Ninomiya, I.; Koike, T. Changes in photosynthesis and leaf characteristics with tree height in five dipterocarp species in a tropical rain forest. Tree Physiol. 2006, 26, 865-873. [CrossRef] [PubMed]

74. Kosugi, Y.; Takanashi, S.; Yokoyama, N.; Philip, E.; Kamakura, M. Vertical variation in leaf gas exchange parameters for a Southeast Asian tropical rainforest in Peninsular Malaysia. J. Plant Res. 2012, 125, 735-748. [CrossRef] [PubMed]

75. Juráň, S.; Pallozzi, E.; Guidolotti, G.; Fares, S.; Šigut, L.; Calfapietra, C.; Alivernini, A.; Savi, F.; Večeřová, K.; Křůmal, K.; et al. Fluxes of biogenic volatile organic compounds above temperate Norway spruce forest of the Czech Republic. Agric. For. Meteorol. 2017, 232, 500-513. [CrossRef]

76. Guidolotti, G.; Calfapietra, C.; Loreto, F. The relationship between isoprene emission, $\mathrm{CO}_{2}$ assimilation and water use efficiency across a range of poplar genotypes. Physiol. Plant. 2011, 142, 297-304. [CrossRef]

77. Tingey, D.T.; Manning, M.; Grothaus, L.C.; Burns, W.F. The influence of light and temperature on isoprene emission rates from live oak. Physiol. Plant. 1979, 47, 112-118. [CrossRef]

78. Llusià, J.; Peñuelas, J. Seasonal patterns of terpene content and emission from seven Mediterranean woody species in field conditions. Am. J. Bot. 2000, 87, 133-140. [CrossRef] [PubMed]

79. Kesselmeier, J.; Ciccioli, P.; Kuhn, U.; Stefani, P.; Biesenthal, T.; Rottenberger, S.; Wolf, A.; Vitullo, M.; Valentini, R.; Nobre, A.; et al. Volatile organic compound emissions in relation to plant carbon fixation and the terrestrial carbon budget. Glob. Biogeochem. Cycles 2002, 16, 1126. [CrossRef]

80. Bracho-Nunez, A.; Knothe, N.M.; Welter, S.; Staudt, M.; Costa, W.R.; Liberato, M.A.R.; Piedade, M.T.F.; Kesselmeier, J. Leaf level emissions of volatile organic compounds (VOC) from some Amazonian and Mediterranean plants. Biogeosciences 2013, 10, 5855-5873. [CrossRef]

81. Loreto, F.; Sharkey, T.D. A gas-exchange study of photosynthesis and isoprene emission in Quercus rubra L. Planta 1990, 182, 523-531. [CrossRef]

82. Larcher, W. Carbon Utilization and Dry Matter Production. In Physiological Plant Ecology: Ecophysiology and Stress Physiology of Functional Groups, 4th ed.; Springer: Berlin/Heidelberg, Germany; New York, NY, USA, 2003; pp. 69-184.

83. Winer, A.M.; Arey, J.; Atkinson, R.; Aschmann, S.M.; Long, W.D.; Morrison, C.L.; Olszyk, D.M. Emission rates of organics from vegetation in California's central valley. Atmos. Environ. 1992, 26, 2647-2659. [CrossRef]

84. König, G.; Brunda, M.; Puxbaum, H.; Hewitt, C.N.; Duckham, S.C.; Rudolph, J. Relative contribution of oxygenated hydrocarbons to the total biogenic VOC emissions of selected mid-European agricultural and natural plant species. Atmos. Environ. 1995, 29, 861-874. [CrossRef]

85. Karl, M.; Guenther, A.; Köble, R.; Leip, A.; Seufert, G. A new European plantspecific emission inventory of biogenic volatile organic compounds for use in atmospheric transport models. Biogeosciences 2009, 6, 1059-1087. [CrossRef]

86. Roberts, J.M.; Williams, J.; Baumann, K.; Buhr, M.P.; Goldan, P.D.; Holloway, J.; Hubler, G.; Kuster, W.C.; McKeen, S.A.; Ryerson, T.B.; et al. Measurements of PAN, PPN, MPAN made during the 1994 and 1995 Nashville Intensives of the Southern Oxidant Study: Implications for regional ozone production from biogenic hydrocarbons. J. Geophys. Res. 1998, 103, 22473-22490. [CrossRef]

87. Wang, K.-Y.; Shallcross, D.E. Modelling terrestrial biogenic isoprene fluxes and their potential impact on global chemical species using a coupled LSM-CTM model. Atmos. Environ. 2000, 34, 2909-2925. [CrossRef]

88. Watson, L.A.; Wang, K.-Y.; Paul, H.; Shallcross, D.E. The potential impact of biogenic emissions of isoprene on urban chemistry in the United Kingdom. Atmos. Sci. Lett. 2006, 7, 96-100. [CrossRef]

89. Hakola, H.; Rinne, J.; Laurila, T. The VOC emission rates of boreal deciduous trees. In Biogenic VOC Emissions and Photochemistry in the Boreal Regions of Europe-Biphorep; European Commission: Brussels, Belgium, 1999.

90. Staudt, M.; Seufert, G. Light-dependent emission of monoterpenes by Holm oak (Quercus ibex L.). Naturwissenschaften 1995, 82, 89-92. [CrossRef]

91. Kesselmeier, J.; Schäfer, L.; Ciccioli, P.; Brancaleoni, E.; Cecinato, A.; Frattoni, M.; Foster, P.; Jacob, V.; Denis, J.; Fugit, J.-L.; et al. Emission of monoterpenes and isoprene from a Mediterranean oak species Quercus ilex L. measured within the BEMA (Biogenic Emissions in the Mediterranean Area) project. Atmos. Environ. 1996, 30, 1841-1850. [CrossRef]

92. Peñuelas, J.; Llusià, J. Short-term responses of terpene emission rates to experimental changes of PFD in Pinus halepensis and Quercus ilex in summer field conditions. Environ. Exp. Bot. 1999, 42, 61-68. [CrossRef]

93. Loreto, F.; Forster, A.; Durr, M.; Csiky, O.; Seufert, G. On the monoterpene emission under heat stress and on the increased thermotolerance of leaves of Quercus ilex L. fumigated with selected monoterpenes. Plant Cell Environ. 1998, 21, 101-107. [CrossRef]

94. Paré, P.W.; Tumlinson, J.H. Plant volatiles as a defense against insect herbivores. Plant Physiol. 1999, 121, 325-332. [CrossRef]

95. Delfine, S.; Csiky, O.; Seufert, G.; Loreto, F. Fumigation with exogenous monoterpenes of a non-isoprenoid-emitting oak (Quercus suber): Monoterpene acquisition, translocation, and effect on the photosynthetic properties at high temperatures. New Phytol. 2000, 146, 27-36. [CrossRef]

96. Peñuelas, J.; Llusià, J. Linking photorespiration, monoterpenes and thermotolerance in Quercus. New Phytol. 2002, 155, $227-237$. [CrossRef] 
97. Copolovici, L.; Kännaste, A.; Pazouki, L.; Niinemets, Ü. Emissions of green leaf volatiles and terpenoids from Solanum lycopersicum are quantitatively related to the severity of cold and heat shock treatments. J. Plant Physiol. 2012, 169, 664-672. [CrossRef]

98. Palmer-Young, E.C.; Veit, D.; Gershenzon, J.; Schuman, M.C. The Sesquiterpenes (E)-B-Farnesene and (E)- $\alpha$-Bergamotene Quench Ozone but Fail to Protect the Wild Tobacco Nicotiana attenuata from Ozone, UVB, and Drought Stresses. PLoS ONE 2015, 10, e0127296.

99. Pazouki, L.; Kanagendran, A.; Li, S.; Kännaste, A.; Memari, H.R.; Bichele, R.; Niinemets, Ü. Mono- and sesquiterpene release from tomato (Solanum lycopersicum) leaves upon mild and severe heat stress and through recovery: From gene expression to emission responses. Environ. Exp. Bot. 2016, 132, 1-15. [CrossRef]

100. Tiiva, P.; Häikiö, E.; Kasurinen, A. Impact of warming, moderate nitrogen addition and bark herbivory on BVOC emissions and growth of Scots pine (Pinus sylvestris L.) seedlings. Tree Physiol. 2018, 38, 1461-1475. [CrossRef] [PubMed]

101. Hildebrand, D.F. Lipoxygenases. Physiol. Plant. 1989, 76, 249-253. [CrossRef]

102. Andersen, R.A.; Hamilton-Kemp, T.R.; Hildebrand, D.F.; McCracken, C.T.; Collins, R.W.; Fleming, P.D. Structure-Antifungal Activity Relationships among Volatile C6 and C9 Aliphatic Aldehydes, Ketones, and Alcohols. J. Agric. Food Chem. 1994, 42, 1563-1568. [CrossRef]

103. Wildt, J.; Kobel, K.; Schuh-Thomas, G.; Heiden, A. Emissions of Oxygenated Volatile Organic Compounds from Plants Part II: Emissions of Saturated Aldehydes. J. Atmos. Chem. 2003, 45, 173-196. [CrossRef]

104. Misztal, P.K.; Hewitt, C.N.; Wildt, J.; Blande, J.D.; Eller, A.; Fares, S.; Gentner, D.; Gilman, J.; Graus, M.; Greenberg, J.; et al. Atmospheric benzenoid emissions from plants rival those from fossil fuels. Sci. Rep. 2015, 5, 12064. [CrossRef]

105. Arimura, G.; Huber, D.P.; Bohlmann, J. Forest tent caterpillars (Malacosoma disstria) induce local and systemic diurnal emissions of terpenoid volatiles in hybrid poplar (Populus trichocarpa $\mathrm{x}$ deltoides): cDNA cloning, functional characterization, and patterns of gene expression of (-)-germacrene D synthase, PtdTPS1. Plant J. 2004, 37, 603-616. [PubMed]

106. Kleist, E.; Mentel, T.F.; Andres, S.; Bohne, A.; Folkers, A.; Kiendler-Scharr, A.; Rudich, Y.; Springer, M.; Tillmann, R.; Wildt, J. Irreversible impacts of heat on the emissions of monoterpenes, sesquiterpenes, phenolic BVOC and green leaf volatiles from several tree species. Biogeosciences 2012, 9, 5111-5123. [CrossRef]

107. Hakola, H.; Rinne, J.; Laurila, T. The hydrocarbon emission rates of tea-leafed willow (Salix phylicifolia), silver birch (Betula pendula) and European aspen (Populus tremula). Atmos. Environ. 1998, 32, 1825-1833. [CrossRef]

108. Copeland, N.; Cape, J.N.; Heal, M.R. Volatile organic compound emissions from Miscanthus and short rotation coppice willow bioenergy crops. Atmos. Environ. 2012, 60, 327-335. [CrossRef]

109. Peräkylä, O.; Vogt, M.; Tikkanen, O.P.; Laurila, T.; Kajos, M.K.; Rantala, P.A.; Patokoski, J.; Aalto, J.; Yli-Juuti, T.; Ehn, M.; et al. Monoterpenes oxidation capacity and rate over a boreal forest: Temporal variation and connection to growth of newly formed particles. Boreal Environ. Res. 2014, 19, 293-310. 